Portland State University

PDXScholar

Spring 6-20-2013

\title{
Preserving Nature through Film: Wilderness Alps of Stehekin and the North Cascades, 1956-1968
}

Nicolas Timothy Bergmann

Portland State University

Follow this and additional works at: https://pdxscholar.library.pdx.edu/open_access_etds

Part of the Forest Management Commons, and the Natural Resources and Conservation Commons Let us know how access to this document benefits you.

\section{Recommended Citation}

Bergmann, Nicolas Timothy, "Preserving Nature through Film: Wilderness Alps of Stehekin and the North Cascades, 1956-1968" (2013). Dissertations and Theses. Paper 973.

https://doi.org/10.15760/etd.973

This Thesis is brought to you for free and open access. It has been accepted for inclusion in Dissertations and Theses by an authorized administrator of PDXScholar. Please contact us if we can make this document more accessible: pdxscholar@pdx.edu. 
Preserving Nature through Film: Wilderness Alps of Stehekin and the North Cascades, 1956-1968

\title{
by
}

Nicolas Timothy Bergmann

\begin{abstract}
A thesis submitted in partial fulfillment of the
\end{abstract} requirements for the degree of

\author{
Master of Arts \\ in \\ Geography

\section{Thesis Committee:} \\ Barbara Brower, Chair \\ William Lang \\ David Banis
}

\section{Portland State University}


(C) Nicolas Timothy Bergmann 2013 


\begin{abstract}
On March 22, 1958 David Brower's film Wilderness Alps of Stehekin premiered to an audience of conservationists in Seattle, Washington. Almost two years in the making, the thirty-one minute film advocated the preservation of nature in Washington's North Cascades through the creation of a national park. Over the next decade, Wilderness Alps of Stehekin became the most influential publicity tool in the struggle to preserve the North Cascades. Because of the region's geographic isolation, the film was the first time many people throughout the nation were exposed to the scenic grandeur of the area. Images of craggy peaks and colorful alpine meadows resonated deeply with many Americans and persuaded them to join in the campaign. It was the voice of these citizens that led Congress to pass the North Cascades Act of 1968, which placed 674,000 acres of the North Cascades under the jurisdiction of the National Park Service.

In this thesis I tell the creation story of North Cascades National Park from a conservationist perspective and trace the influence of Wilderness Alps of Stehekin within this context. Although the film was never shown in movie theaters and never aired on national television, many thousands viewed it from its premiere to the signing of the North Cascades Act. The film first introduced the idea of a North Cascades National Park, and it was important in convincing conservationists to unite around a national park solution. Ultimately, Wilderness Alps of Stehekin changed the approach activists took in the North Cascades and helped to preserve a wild and scenic nature experience for future generations through the protection of old-growth forests and alpine meadows.
\end{abstract}


For all those who gave so much to preserve the North Cascades and all those who still do. 


\section{Acknowledgements}

Over the past two years, this project has evolved from an idea tossed around in a classroom discussion to a Master's thesis. Along the way I have received a tremendous amount of assistance from many individuals, and I would now like to recognize them.

First, I want to thank Barbara Brower, my advisor, for guiding me through this process and for supporting me on a project that is very personal to her. As the daughter of David Brower, Barbara was a bit dismayed the afternoon I proposed a project featuring her father. Nevertheless, despite any misgivings, her counsel has been invaluable, and I owe her a great debt of gratitude. Next, I would like to thank the other members of my thesis committee, William Lang and David Banis, for their critiques of my project and for their help in shaping my research goals. I also want to thank Karin Waller, our Office Coordinator, for her tireless work behind the scenes.

My graduate assistantship, split between the Department of Geography and the Oregon Geographic Alliance, made my time at Portland State University financially feasible. I would like to thank Joe Poracsky and Teresa Bulman for providing this opportunity. I would also like to thank the Oregon Community Foundation for a grant that allowed me to take two field trips into the North Cascades, travel across the country to conduct interviews, and spend significant time at the University of Washington Special Collections in Seattle and the Bancroft Library in Berkeley.

My work in the archives at the University of Washington was made easier through the assistance of Gary Lundell, who helped a first timer find the necessary material. Lauren Lassleben, archivist at the Bancroft Library, helped me navigate the massive Sierra Club collections; without her, my stay in Berkeley would have been far 
less fruitful. I owe a huge thank you to Sierra Club Librarian Ellen Byrne for sending me a copy of Wilderness Alps of Stehekin; the film is not easy to find.

I would like to extend a special thank you to J. Michael McCloskey, Ann McConnell, Brock Evans, and Kenneth Brower for sparing a few hours of their time to talk with me about the film. Their personal experience with Wilderness Alps of Stehekin and the North Cascades has added color and life to my thesis.

I would also like to extend a warm thank you to Marc Cogan for making his delicious chili; to Bob Nielson, who put me in contact with Ann McConnell; Wendy Walker and the Western Washington University's Spring Block 2012 for sharing their Stehekin experience with me; Scott MacDonald for his enthusiasm, advice, and encouragement regarding the project; and my aunt Beth Bidstrup for her generosity while we were both in Berkeley.

Lastly, I would like to thank my family and friends for all their support. Henry Underwood, my chief cartographer, fellow graduate student, roommate, and great friend spent many hours making several maps for this thesis; his skill as a mapmaker is evident, and I am grateful for his willingness to participate. Frank Bergmann, my father and chief editor, currently a visiting professor at Jagiellonian University in Kraków, Poland, found time to scrutinize the text; any smoothness in my prose is a credit to him. Most of all, I would like to thank my girlfriend Kirsten Moore for not only putting up with this project but encouraging me every step of the way. Kirsten's beautiful hand drawn map and stunning photographs may be her most visible contribution to the project, but it is really her unwavering support and companionship throughout this seemingly endless project that have meant the most. Thank you. 


\section{Contents}

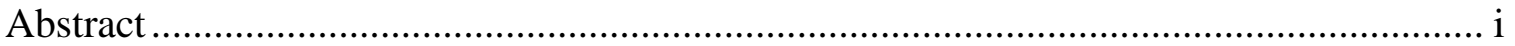

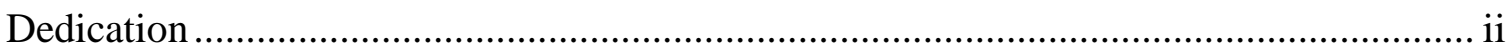

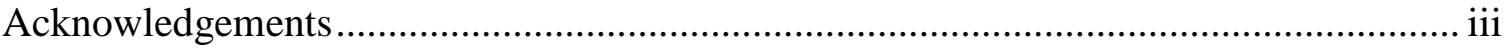

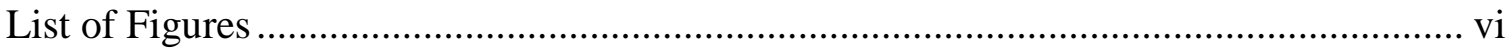

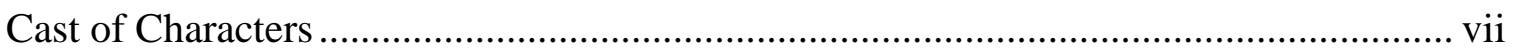

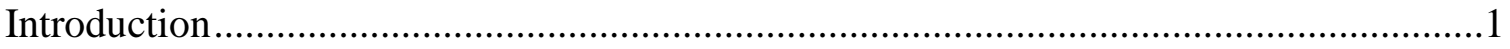

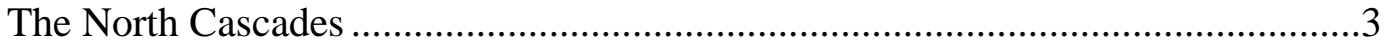

United States Forest Service vs. National Park Service ....................................4

David Brower and the film Wilderness Alps of Stehekin ......................................

Part 1: The Antecedent: Dinosaur National Monument ...................................................

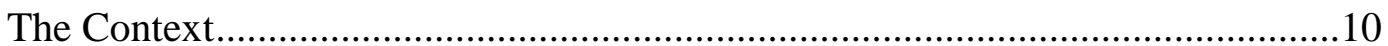

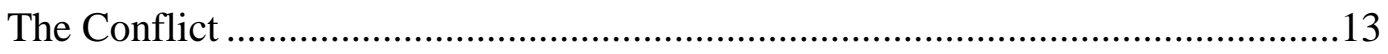

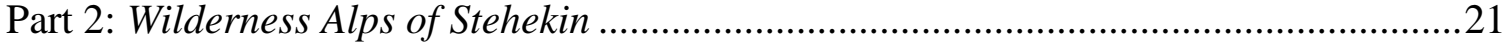

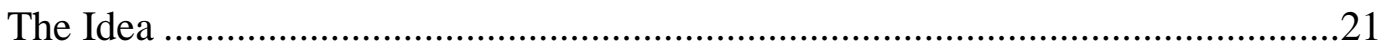

David Brower: Amateur Filmmaker .......................................................25

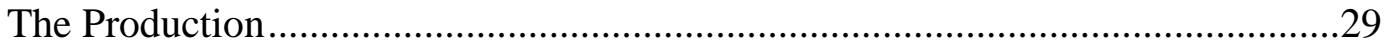

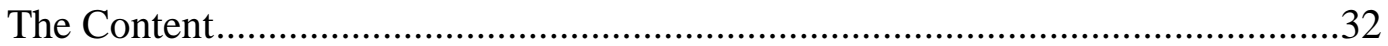

Part 3: A National Park for the North Cascades? ............................................................47

Grant McConnell: Voice of Stehekin ..............................................................48

Forest Service and Wilderness Areas: The 1950s in the North Cascades .............51

1958: The Year Conservationists Unite ..........................................................57

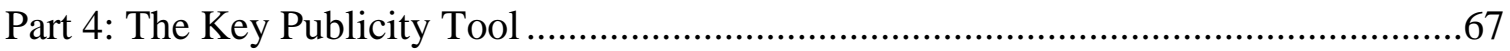

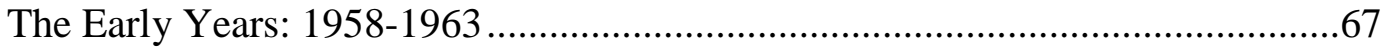

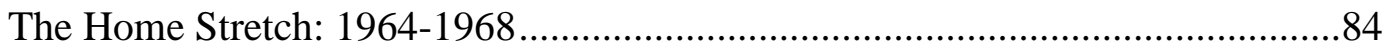

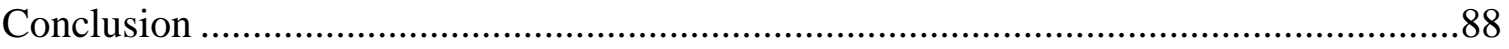

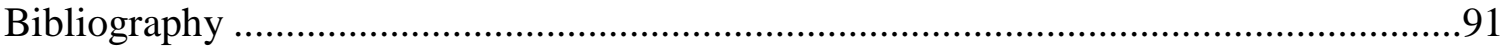




\section{List of Figures}

Figure 1. The North Cascades of Washington State .................................................. 1

Figure 2. The Location of Dinosaur National Monument .............................................11

Figure 3. The Wilderness Alps of Stehekin ...........................................................28

Figure 4. Nationwide Distribution of Wilderness Alps of Stehekin (January 1962) ..........70

Figure 5. Proposed North Cascades National Park .....................................................82

Figure 6. North Cascades National Park and Wilderness Areas (October 2, 1968) .........88 


\section{Cast of Characters:}

Adams, Ansel - Sierra Club member and one of the world's greatest nature photographers. Adams heavily influenced David Brower's visual consciousness and development as a filmmaker.

Avery, Abigail - Friend of the McConnells. She provided the funding necessary to complete Wilderness Alps of Stehekin.

Brower, David - First Executive Director of the Sierra Club and producer of Wilderness Alps of Stehekin. Brower was a leading advocate for a national park in the North Cascades encompassing Glacier Peak, Eldorado Peaks, Stehekin Valley, and Lake Chelan.

Bureau of Reclamation - Government agency founded in 1902 as the United States Reclamation Service. Proposed building dams inside Dinosaur National Monument at Echo Park and Split Mountain as part of the Colorado River Storage Project.

Clark, Nathan - Sierra Club member. He shot footage for Wilderness Alps of Stehekin in the summer of 1956. Unfortunately, Clark made mistakes in the processing of the film, and almost all the footage he captured became worthless.

Conservation Film Center - Founded in April, 1964 by Louis R. Huber and Margaret Tjaden. It centralized the film holdings by conservation organizations in Washington State and facilitated the distribution of nine copies of Wilderness Alps of Stehekin from 1964-1968.

Dyer, Polly - Past President of the Federation of Western Outdoor Clubs. Dyer was a key member of the North Cascades Conservation Council and held many showings of Wilderness Alps of Stehekin.

Eggert, Charles - Professional filmmaker and Director of Motion Pictures for the National Parks Association. He helped David Brower edit Wilderness Alps of Stehekin.

Goldsworthy, Patrick - Second President of the North Cascades Conservation Council. Goldsworthy was a leader of the conservationist movement to preserve the North Cascades in the 1960s.

Jackson, Henry M. - Washington State's Senior Senator and chairman of the Senate Committee on Interior and Insular Affairs. Jackson was the key politician in the controversy. Conservationists needed Jackson's support in order for a national park in the North Cascades to become a reality.

Manning, Harvey - North Cascades Conservation Council member and author of a Sierra Club Exhibit-Format series book on the North Cascades. 
Marshall, Robert "Bob" - Co-founder of the Wilderness Society and proponent of designating wilderness areas on federal lands. Marshall proposed a 794,440-acre wilderness area encompassing Glacier Peak in the late 1930s.

McArdle, Richard - Chief of the United States Forest Service from 1952 to 1962. McArdle was not a proponent of the wilderness designation. Instead, he favored a policy of multiple-use for Forest Service-managed lands.

McCloskey, J. Michael - Represented conservationist organizations in the Pacific Northwest from 1961-1963. McCloskey edited the Prospectus for a North Cascades National Park, which outlined in detail the conservationists' proposal for a national park.

McConnell, Grant - Professor of Political Science at the University of California and the University of Chicago. McConnell owned a cabin in Stehekin and was vehemently opposed to proposed logging in the Agnes Creek Valley. He was one of the most important conservationists in the fight to preserve the North Cascades.

National Park Service - Government agency founded in 1916. The Park Service manages all of the country's national parks, most national recreation areas, national monuments, and a number of other federal land designations. The 1968 North Cascades Act placed North Cascades National Park (505,000 acres), Ross Lake National Recreation Area (107,000 acres), and Lake Chelan National Recreation Area (62,000 acres) under the jurisdiction of the Park Service.

North Cascades Conservation Council (NCCC) - Conservation organization founded in 1957. The NCCC was concerned primarily with the preservation of the North Cascades. It played a critical role in gathering support for a North Cascades National Park within Washington State.

Sierra Club - Conservation organization based in San Francisco, California. Founded in 1892 by John Muir and other Bay Area residents. The Sierra Club played a leading role in the production of Wilderness Alps of Stehekin and focusing conservation energy on a national park solution for the North Cascades.

Simons, David - Conservationist prodigy. Simons, along with Brower and McConnell, set the national park agenda for the North Cascades. Simons's influential brief provided detailed rationalization for a national park solution.

United States Forest Service - Government agency founded in 1905. The USFS manages all of the country's national forests and a few of its national monuments. The Forest Service managed all federal land in the North Cascades until the North Cascades Act of 1968 transferred 674,000 acres to the National Park Service. 
The Wilderness Society - Conservationist organization founded in 1935 by Robert Marshall, Aldo Leopold, and other leading conservationists. The Wilderness Society was focused primarily on designating land as "wilderness." After the victory at Dinosaur National Monument, the organization focused its energy on persuading Congress to pass the Wilderness Act.

Wirth, Conrad - Director of the National Park Service from 1951 to 1964 and member of the Wilderness Society. In 1958, conservationists convinced Wirth to favor a North Cascades National Park.

Zahniser, Howard - Executive Secretary of the Wilderness Society and author of the Wilderness Act. Zahniser was a tireless promoter of preserving America's natural beauty. He was especially effective at influencing members of Congress.

Zalesky, Philip - First President of the North Cascades Conservation Council. Zalesky initially opposed a national park solution for the North Cascades. 


\section{Introduction}

\section{The North Cascades of Washington State}

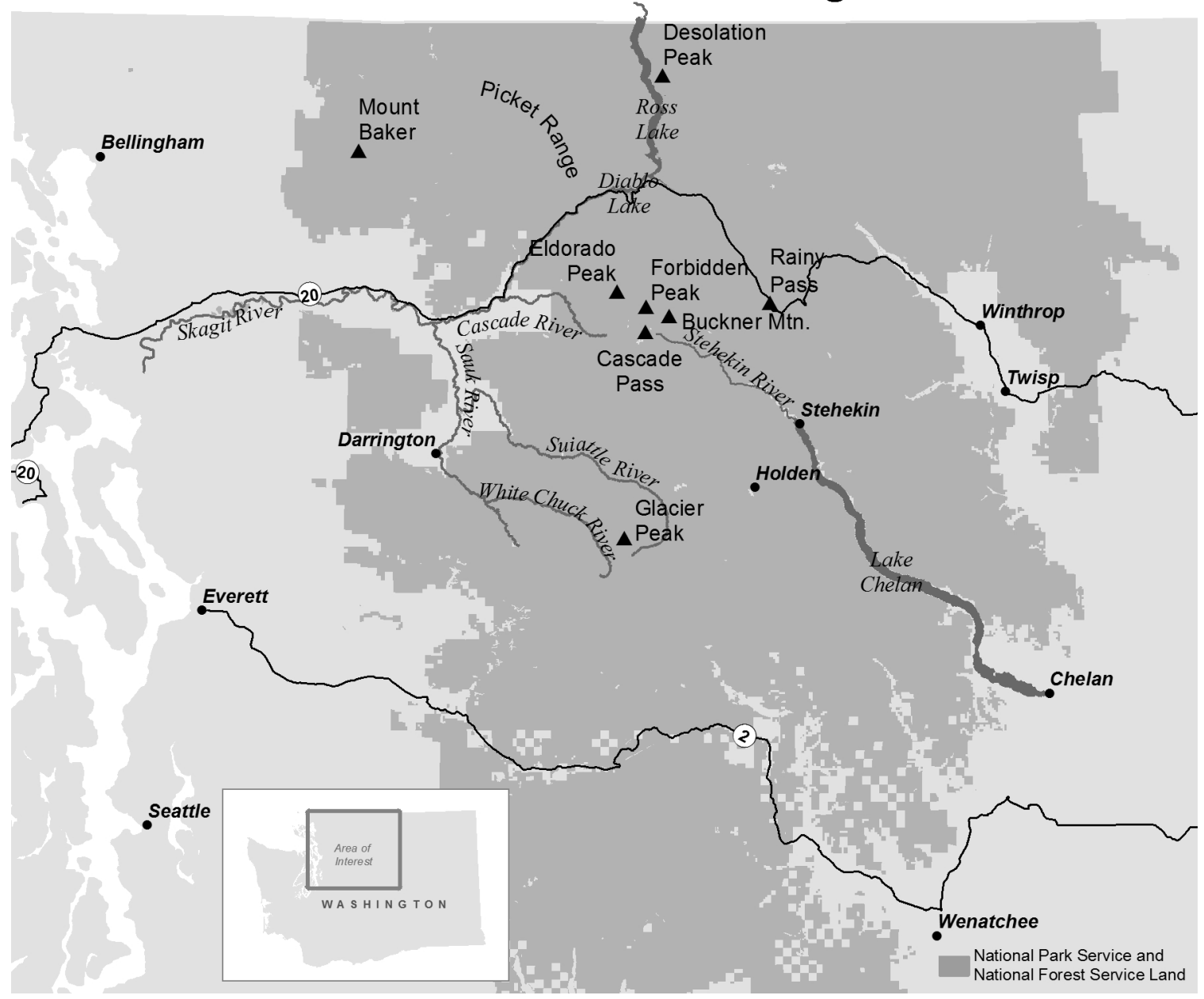

Figure 1. The North Cascades of Washington State ${ }^{1}$

In the late 1950s conservationist David Brower produced a thirty-one minute color film entitled Wilderness Alps of Stehekin. The purpose of the film was to attract widespread support for the preservation of a portion of the North Cascades as a national park. It targeted both conservationists and the public in general and, despite its low budget and amateur cast, proved an extremely persuasive and successful advocacy tool. The success of the film derived from its breathtaking alpine footage, lyrical narration,

\footnotetext{
${ }^{1}$ Henry Underwood, “The North Cascades of Washington State,” Map, 2013.
} 
clear focus, compelling soundtrack, and family-oriented storyline. Its message resonated with an increasing number of Americans who wished to protect and experience the nation's wild and scenic beauty. From its premiere on the night of March 22, 1958 to the signing of the North Cascades Act on October 2, 1968, Wilderness Alps of Stehekin was shown many times around the country, reaching many thousands of people. ${ }^{2}$ The film not only gave many Americans their first glimpse of the region but also inspired them to donate their time, money, and voice in support of a North Cascades National Park. Wilderness Alps of Stehekin was the most important publicity tool conservationists possessed in the struggle to preserve the North Cascades.

In this thesis I demonstrate the critical significance of Wilderness Alps of Stehekin in the passage of the North Cascades Act of 1968 and the creation of a North Cascades National Park. ${ }^{3}$ I recount the history of the North Cascades conflict largely from the perspective of conservationists and examine the effect of the film within this context. This thesis focuses on a specific storyline from the North Cascades struggle and does not emphasize other important aspects of the fight such as natural resource politics and dynamics between private industry and government bureaucracies. It is not intended to be a comprehensive history of the conflict.

\footnotetext{
${ }^{2}$ See Harvey Manning, Wilderness Alps: Conservation and Conflict in Washington's North Cascades, ed. Ken Wilcox (Bellingham: Northwest Wild Books, 2007), 108.

${ }^{3}$ Key publications on this controversy in the North Cascades include Kevin R. Marsh, Drawing Lines in the Forest: Creating Wilderness Areas in the Pacific Northwest (Seattle: University of Washington Press, 2007), 38-60; David Louter, Contested Terrain: North Cascades National Park Service Complex, An Administrative History (Seattle: National Park Service, 1998), 9-57; Allan Sommarstrom, "Wild Land Preservation Crisis: The North Cascades Controversy" (PhD dissertation, University of Washington, 1970); Lauren Danner, "Cultural Values and Communication Content: The Environment and Washington State in the 1960s" (PhD dissertation, University of Oregon, 1999), 132-189; David Louter, Windshield Wilderness: Cars, Roads, and Nature in Washington's National Parks (Seattle: University of Washington Press, 2006), 105-133; Harvey Manning, Wilderness Alps, 79-198.
} 
The North Cascades Act established a 505,000-acre North Cascades National Park, a 107,000-acre Ross Lake National Recreation Area, and a 62,000-acre Lake Chelan National Recreation Area under the jurisdiction of the National Park Service. Land under these designations gained increased protection from resource extraction and scenic degradation. Ultimately, the passage of the North Cascades Act of 1968 was significant to many Americans because it protected 674,000 acres of the North Cascades for the enjoyment of future generations.

\section{The North Cascades}

The North Cascades are a mountainous region in Washington State geographically bounded in the south by Stevens Pass and in the north by the Canadian border. In terms of aesthetic appearance, the North Cascades look similar to the European Alps and therefore are often referred to as the American Alps. Although the absolute vertical elevation of the range rarely eclipses ten thousand feet, its location and climate have made it home to the greatest concentration of glaciers in the contiguous United States. The effect of glaciers on the landscape is significant. High cirque basins, craggy peaks, and deep U-shaped river valleys provide dramatic beauty. Moreover, the valleys offer not only incredible contrast to the high mountains but are also home to verdant oldgrowth forests that sweep up onto the sides of formidable peaks and to a variety of animals such as porcupines, pine martens, and bears.

Like other North American mountain ranges that run north to south, a contrast in climate and vegetation exists between the western and eastern portions of the range. Because of effects from orographic lifting, the western slopes of the North Cascades 
receive much more precipitation than their eastern counterparts. Consequently, stands of Douglas fir, western hemlock, and western red cedar are prevalent on the west side of the range, while drier tree species such as grand fir and ponderosa pine dominate the vegetation of the eastern side. Human settlement patterns have also influenced the region's geography. High population density on the west side of the range provided the impetus for water development projects on the Skagit River, which created Diablo Lake and Ross Lake. Smaller settlements located on the east side of the range have also played a substantial role in shaping the geography of the area. The North Cascades Highway, which runs west to east across the region, was constructed to facilitate transportation between locations on both sides of the range.

\section{United States Forest Service vs. National Park Service}

The idea for a national park in the North Cascades began in the 1950s when a group of conservationists became dissatisfied with the acreage the United States Forest Service was willing to designate as wilderness. ${ }^{4}$ Seattle-based conservationists had urged the Forest Service in the early and mid 1950s to designate nearly 800,000 acres of wild and scenic land in the North Cascades as wilderness. ${ }^{5}$ However, when the Forest Service released its Glacier Peak Wilderness Area proposal in February 1957, it proposed to designate only 434,310 acres as wilderness. Frustrated with the Forest Service's refusal to

\footnotetext{
${ }^{4}$ See Louter, Contested Terrain, 10-25. Multiple attempts at establishing a national park in the North Cascades were made before World War II. All of these attempts failed. This was the first attempt in the postwar era.

${ }^{5}$ See Marsh, Drawing Lines, 23-24. The Forest Service first began to institutionalize nation forest wilderness in 1929 with its L-20 regulations in response to urgings by Arthur Carhart and Aldo Leopold. Ten years later, it created its U-Regulations. These standards allowed the Secretary of Agriculture to designate certain areas larger than 100,000 acres in national forests as wilderness areas. Wilderness as a designation would not gain legal status until the passage of the 1964 Wilderness Act, which gave Congress sole authority to designate wilderness areas on all federal lands.
} 
protect an adequate amount of land, three Sierra Club activists, David Brower, Grant McConnell, and David Simons, began to formulate a plan to preserve the North Cascades as a national park. These three men believed that National Park Service management of the area offered better protection.

Brower, McConnell, and Simons were proposing a radical idea. During the 1950s almost all land in the North Cascades was held in national forests. Since 1905, the Forest Service had managed these national forest lands. ${ }^{6}$ The authority to manage national parks, on the other hand, rests with the National Park Service. ${ }^{7}$ A national park in the North Cascades would require a land transfer between the Forest Service and the Park Service. Convincing Congress to transfer Forest Service land to the Park Service was a monumental task. The Forest Service stood to gain nothing from a land transfer, and historically the Forest Service had lost jobs and funding when Congress created national parks from national forest lands. Moreover, the Park Service did not have much interest in managing lands in the North Cascades in the 1950s. In order for a national park in the North Cascades to become a reality, Brower, McConnell, and Simons would need to convince other conservationists of its value, persuade the Park Service that portions of the North Cascades were worthy of national park protection, and convince Congress to pass legislation establishing a North Cascades National Park.

Many conservationists were wary of a national park solution because they did not believe the National Park Service was the best agency for preserving wild lands.

\footnotetext{
${ }^{6}$ See Louter, Contested Terrain, 14-15. The Forest Reserve Act of 1891 gave the President of the United States executive privilege to establish forest reserves. On February 22, 1897 President Grover Cleveland established the Washington Forest Reserve covering much of the North Cascades. In 1908 the United States Forest Service split the Washington Forest Reserve into Chelan National Forest and Washington National Forest.

${ }^{7}$ On August 25, 1916 Congress passed an act creating the National Park Service.
} 
Although known as a preservation-minded agency, the Park Service was mandated "to conserve the scenery and the natural and historic objects and the wildlife therein and to provide for the enjoyment of the same in such manner and by such means as will leave them unimpaired for the enjoyment of future generations.." ${ }^{\prime 8}$ Therefore, the Park Service was charged from its founding with the incompatible tasks of making its land accessible for the enjoyment of people yet leaving it "unimpaired." In order to make national parks and monuments under its control enjoyable to the public, the Park Service developed miles upon miles of roads, visitor centers, gas stations, and general stores. Many Seattlebased conservationists feared Park Service control of the North Cascades in the 1950s because they thought that the agency would destroy the wildness of the land through the construction of roads and accommodations for tourism. Thus, it was not faith in the Park Service's ability to preserve wild land but a lack of faith in the Forest Service's ability that persuaded conservationists to unite around the idea of a national park in the North Cascades.

In the years after World War II, Forest Service management in the North Cascades and across the nation began to change. A postwar economic boom saw both an increased demand for wood-based construction materials and the emergence of a growing middle class increasingly interested in enjoying America's national parks and forests. As the price of timber increased and private timberlands were depleted, the agency responded by awarding more logging contracts in national forests, including those in the North Cascades. Conservationists concerned about the region's natural integrity were becoming agitated over increased logging activity. The Forest Service's failure in

\footnotetext{
${ }^{8}$ Act of 25 August 1916. 39 Stat. 535.
} 
February 1957 to allocate adequate territory to wilderness convinced Brower, McConnell, and Simons to push for a national park in the North Cascades. Their first priority was convincing other conservationists to change their position to favor Park Service control of the Glacier Peak, Eldorado Peaks, Lake Chelan, and Stehekin Valley regions of the North Cascades.

\section{David Brower and the film Wilderness Alps of Stehekin}

David Brower understood the persuasive power of visual imagery and used Wilderness Alps of Stehekin to introduce the national park idea to conservationists in March 1958. When combined with David Simons's June 1958 brief entitled "The Need for Scenic Resource Conservation in the Northern Cascades of Washington," the film persuaded many conservationists to change their position and unite in favor of a national park. With a solidified base of support, Brower and McConnell were soon able to convince pivotal employees of the Park Service that portions of the North Cascades were worthy of national park status. After accomplishing these tasks, conservationists needed to convince Congress to pass legislation in favor of a North Cascades National Park. Wilderness Alps of Stehekin was the key tool in this effort. Although the film was shown to a handful of congressmen, its real power lay in its ability to convince the American public of the North Cascades's scenic grandeur and the necessity of preserving that grandeur as a national park.

In the late 1950s most Americans were unaware of the incredible nature experiences available in the North Cascades because of the region's geographic isolation. Consequently, visual imagery played an exceptionally important role in the preservation 
of the region. Wilderness Alps of Stehekin proved extremely effective at influencing public opinion on both the local and national levels and uniting conservationists around the national park idea. A major reason for the film's popularity was its timing. David Brower and the Sierra Club produced Wilderness Alps of Stehekin in an era when conservation issues were gaining greater attention. In order to strengthen popular enthusiasm for nature and capture support for wild and scenic protection, conservationists used color photography and film. The power of visual imagery was indispensable in mobilizing support for preservation. Whether through photographs or films, images of nature's beauty resonated with Americans and persuaded them to act. Ultimately, it was the voice of these people that would convince congressmen across the United States to preserve a substantial section of the North Cascades as a national park. ${ }^{9}$

This thesis is divided into four parts. The first part explores the effect of Dinosaur National Monument on the postwar conservation movement and its role as an antecedent to the crisis in the North Cascades. The second part focuses on Wilderness Alps of Stehekin's production and content. The third part deals with the formation of the national park idea in the North Cascades and the role of the film in this process. The final part examines the role of the film as a publicity tool from its premiere in March 1958 until the signing of the North Cascades Act in October 1968.

\footnotetext{
${ }^{9}$ For the importance of color photography and film in the postwar conservation movements see Samuel P. Hays, Beauty, Health, and Permanence: Environmental Politics in the United States, 1955-1985 (New York: Cambridge University Press, 1987), 37; Finis Dunaway, Natural Visions: The Power of Images in American Environmental Reform (Chicago: University of Chicago Press, 2005), 117-147; Gregg Mitman, Reel Nature: America's Romance with Wildlife on Film (Cambridge, MA: Harvard University Press, 1999), 85-131.
} 


\section{Part 1: The Antecedent: Dinosaur National Monument}

While Seattle-based conservationists were urging the designation of a Glacier Peak Wilderness Area in the North Cascades, the most important conservation battle of the 1950s was occurring hundreds of miles away at Dinosaur National Monument. Although not a conflict between the United States Forest Service and conservationists, in many ways the battle over Dinosaur National Monument laid the groundwork for the production of Wilderness Alps of Stehekin and the strategy conservationists implemented in their North Cascades campaign.

Despite being the premier conservation organization in California during the first half of the twentieth century, the Sierra Club was primarily a small regional climbing club until its involvement at Dinosaur National Monument. David Brower, the Sierra Club's first executive director, was one of the key conservation leaders in the struggle. ${ }^{10}$ Brower's passion for protecting natural landscapes was grounded in his experiences mountaineering in the Sierra Nevada. Known as one of America's leading climbers in the 1930s, Brower pioneered numerous routes up some of the range's most challenging peaks. His most publicized climbing achievement occurred in 1939, when he and three climbing partners made a stunning first ascent of New Mexico’s Shiprock. ${ }^{11}$

As Brower became a professional conservation advocate in the early 1950s, his charisma, leadership, publicity skill, and gift for understanding the power of visual imagery proved indispensible. Brower played a major role in the production of two films about Dinosaur National Monument: Wilderness River Trail and Two Yosemites. The

\footnotetext{
${ }^{10}$ David Brower became the Sierra Club's first executive director in December 1952.

${ }^{11}$ John Dyer, husband of conservationist Polly Dyer, was one of the three climbing partners.
} 
films were key publicity tools for conservationists and helped them create a great deal of public support against the damming of the Green and Yampa Rivers.

Aside from Brower's emergence as a leader in the conservation movement, the growth in power and influence of the Sierra Club, and the development of David

Brower's filmmaking ability, Dinosaur National Monument was important because it was the first time conservationists had united on a major conservation issue and defeated a powerful government agency. The conservationist victory at Dinosaur National Monument over the Bureau of Reclamation signaled the arrival of a new political force and gave conservationists the confidence to take on the Forest Service in the North Cascades. Moreover, the victory at Dinosaur National Monument reaffirmed the sanctity of the national park system and gave it further legal protection from development. ${ }^{12}$ This victory for the national park system played a crucial role in David Brower's decision to push for a national park in the North Cascades.

\section{The Context}

In 1915 President Woodrow Wilson first created Dinosaur National Monument to protect 80 acres of dinosaur remains. More than two decades later, in 1938, President Franklin D. Roosevelt enlarged the area to over 200,000 acres. $^{13}$ The new enlargement gave protection to "approximately one hundred miles of the deep, isolated canyons of the Green and Yampa Rivers plus the surrounding benchland" and "literally overnight, a tiny

\footnotetext{
${ }^{12}$ The CRSP bill included explicit language "that the legislation would not permit any dam or reservoir from intruding into any part of the national park system" including Rainbow Bridge National Monument; see Mark W. T. Harvey, A Symbol of Wilderness: Echo Park and the American Conservation Movement (Albuquerque: University of New Mexico Press, 1994), 278-283. Nevertheless, water from Lake Powell would later "intrude" on Rainbow Bridge National Monument (in clear violation of the bill).

${ }^{13}$ The Antiquities Act of 1906 gave the President of the United States the power to designate areas of public land as national monuments.
} 
national monument in northeast Utah became one of the biggest areas in the national park system." The National Park Service and local residents rejoiced at the expansion of the monument. Few people, if any, could have anticipated the prolonged battle over a dam at Echo Park that would be the definitive conservation issue of the 1950s and would set the tone for a future preservation battle in the North Cascades. ${ }^{14}$

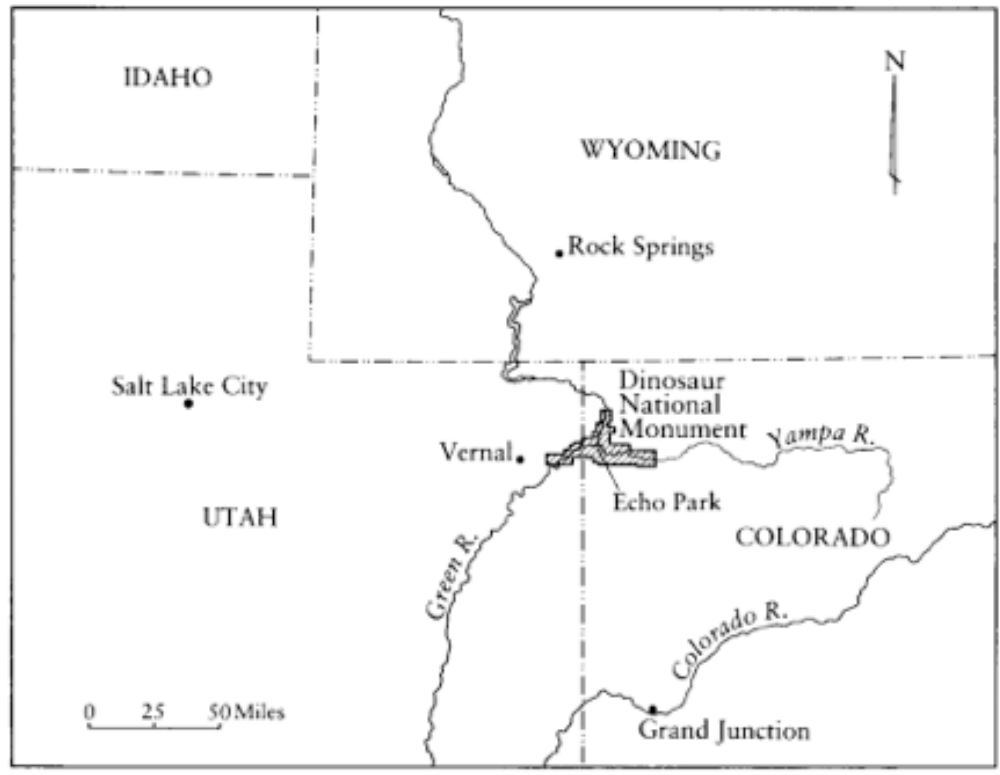

Figure 2. The Location of Dinosaur National Monument. ${ }^{15}$

The reason for the lack of foresight regarding Dinosaur was World War II. Before the war broke out in 1939, the upper Colorado basin did not have the population or industrial base to push for major dam projects. However, the war stimulated tremendous economic growth in the region, which placed "ever increasing attention on water and

\footnotetext{
${ }^{14}$ First quotation: Nash, Wilderness, p. 209; Second quotation Harvey, Symbol of Wilderness, p. 14; for a brief description of the controversy over Dinosaur National Monument see Nash, Wilderness, pp. 209-219 and Stephen Fox, The American Conservation Movement: John Muir and His Legacy (Madison, The University of Wisconsin Press, 1981) pp. 281-286; For the definitive history of Echo Park see Harvey, Symbol of Wilderness.

${ }^{15}$ Harvey, Symbol of Wilderness, 25.
} 
power supplies, and elevated the value of the Colorado River."16 Thus, in the years following World War II, Utah, Wyoming, Colorado, and New Mexico attempted to develop their legal right to the Colorado River using the largesse of the federal government.

The Colorado River Storage Project (CRSP) was the brainchild of the Bureau of Reclamation. As the most powerful unit of the Department of the Interior at this time, the Bureau of Reclamation had the clout and reputation to propose and undertake monumental projects. In the first half of the twentieth century, the Bureau of Reclamation built the two most iconic dams in the American West-Hoover and Grand Coulee. These dams gave the nation "proof that science, technology, and a dash of ingenuity could lift the country out of its doldrums." ${ }^{\prime 17}$ In order to develop the upper Colorado River, Utah, Wyoming, New Mexico, and Colorado turned to the Bureau of Reclamation. The Bureau's plan outlined in its 1946 report “A Natural Menace Becomes a Natural Resource" illustrated a combination of dams, power plants, and irrigation works to harness the great river and further industrialize these states. Grandiose in its ambition and breadth, the CRSP highlighted the power of the Bureau of Reclamation. ${ }^{18}$ Central to the CRSP were two dams within Dinosaur National Monument. The larger dam proposed near Echo Park was an ideal location in the eyes of dam proponents. The smaller dam located at Split Mountain Canyon would stand east of the Echo Park site and serve as a subsidiary dam. ${ }^{19}$

\footnotetext{
${ }^{16}$ Harvey, Symbol of Wilderness, 36.

${ }^{17}$ Harvey, Symbol of Wilderness, 25.

${ }^{18}$ Harvey, Symbol of Wilderness, 42.

${ }^{19}$ Harvey, Symbol of Wilderness, 29.
} 
The population increase and economic boom created by World War II and its aftermath not only brought calls for development from upper basin states and the Bureau of Reclamation but also strengthened the voice of conservationists in the American West. Conservation organizations came to the defense of Dinosaur National Monument because the dam proposal symbolized "mounting pressures on the national park system." ${ }^{20}$ This system, first established in the late nineteenth century, protected some of America's finest landscapes. ${ }^{21}$ Conservation organizations saw water development projects as impediments in preserving the natural beauty of these areas. Consequently, these organizations opposed the building of dams at Echo Park and Split Mountain in Dinosaur National Monument.

\section{The Conflict}

The controversy over Dinosaur National Monument began in earnest with Secretary of the Interior Oscar Chapman's approval of the two dams slated for Dinosaur National Monument in June 1950. National Park Service director Newton Drury strongly opposed dams and reservoirs located within national parks and monuments. Drury had suggested alternative sites for the dams, but the Bureau of Reclamation had insisted on the dams within Dinosaur. Chapman's approval frustrated Drury, and he "expressed his clear disappointment with Chapman's leadership at the Interior Department." Less than a

\footnotetext{
${ }^{20}$ Harvey, Symbol of Wilderness, 51.

${ }^{21}$ The origin of the national park system can be traced to June 30, 1864. On that day, President Abraham Lincoln signed into law a congressional act protecting the area around Yosemite Valley and the Mariposa Grover of giant sequoias. Congressional protection of Yosemite Valley paved the way for America's first national park. Established in 1872, Yellowstone National Park preserved 3,500 square miles of geological phenomenon. In 1890 Congress created Yosemite National Park, General Grant National Park, and Sequoia National Park in California. In 1899 Congress added over 200,000 acres encompassing Washington's Mount Rainier to the system.
} 
year later, in early 1951, Chapman requested Drury’s resignation, which “caused an uproar among conservation groups in the United States and brought the Dinosaur controversy into the public arena., 22

Although Drury's resignation caused public outrage among conservation groups, Dinosaur needed more than the forced resignation of a government official to enter the public spotlight. Shortly after Chapman made his decision to approve the dams, an article appeared in the Saturday Evening Post entitled "Shall We Let Them Ruin Our National Parks?" The article, by Bernard DeVoto, brought the issue of Dinosaur to the attention of a far greater audience. As Mark W. T. Harvey writes,

The article delivered a tremendous punch. While members of the Wilderness Society and the National Parks Association already knew about the proposed dam, generally conservation-minded Americans did not. It carried a strong sense of alarm that caught the attention of thousands of people who could help: the rank and file members of the Audubon Society, the Sierra Club, the Izaak Walton League and dozens of other organizations not yet aware of the controversy. ${ }^{23}$

The mobilization and unification of conservationists in order to protect Dinosaur National Monument and the sanctity of the national park system had begun.

Despite Drury's forced resignation and DeVoto's article, many Americans still had no idea where Dinosaur was and why it would be worth saving. The Sierra Club and other conservation organizations embarked on a publicity campaign for the monument. Two Sierra Club films, Wilderness River Trail and Two Yosemites, helped to transform Dinosaur from a place hardly anyone knew into a well-known location of natural beauty in the American West. The Sierra Club, at the suggestion of its Conservation Committee Chair Harold Bradley, organized trips for its members and, under the leadership of its

\footnotetext{
${ }^{22}$ Harvey, Symbol of Wilderness, 77.

${ }^{23}$ Harvey, Symbol of Wilderness, 95.
} 
new executive director David Brower, took the lead in promoting Dinosaur's scenic beauty through visual imagery. The club ran three river trips through the canyons of the Green and Yampa Rivers in the summer of 1953. Although historically an organization focused solely on Sierra Nevada conservation issues, the Sierra Club embraced a new challenge by helping to preserve Dinosaur. ${ }^{24}$

The most important outcome of the club's 1953 river trips was not any personal memory or life-changing experience but footage professional photographer Charles Eggert shot for a film about Dinosaur. Heavily influenced by David Brower, Wilderness River Trail captured the wilderness qualities of the place. David Brower described the contents of the film as

A joyful trip for people of all ages, two little lads exploring enticing places from riverside camps, spectacular colorful cliffs passing by, some exciting rapids, quiet camping, then a switch to the threat, with Clair Leonard's music, composed and performed on the Bard College pipe organ, augmenting each section.

The Sierra Club made fourteen copies of the film, which were held by various conservation organizations throughout the nation. Moreover, the film was shown to thousands of "conservation and wilderness enthusiasts around the country," and David Brower recounted that even the Bureau of Reclamation believed that Wilderness River Trail was "the most effective weapon we had in saving Dinosaur National Monument.",25 The 1952 election cycle saw a change of leadership in the White House. President Eisenhower appointed former Oregon governor Douglas McKay as Secretary of the Interior. Facing pressure from the Army Corps of Engineers and conservation groups,

${ }^{24}$ Harvey, Symbol of Wilderness, 164-166.

${ }^{25}$ Brower, Work in Progress, 47-48; Harvey, Symbol of Wilderness, 167; David R. Brower, "Environmental Activist," 113; see also David Louter, Contested Terrain, 31. 
Oscar Chapman had rescinded his early approval of a dam near Echo Park in December 1952 and left the decision up to his successor. The following December, Secretary McKay, acting on advice from his undersecretary Ralph Tudor, approved the first phase of the Colorado River Storage Project, which included a dam near Echo Park. McKay justified Echo Park's inclusion based on its lower evaporation rates. ${ }^{26}$

Debate over the fate of Dinosaur National Monument soon turned to Congress. The House Subcommittee on Irrigation and Reclamation held hearings regarding the CRSP in late January 1954. At the hearings David Brower was able to shed doubt on the accuracy of the Bureau of Reclamation's evaporation figures using his "ninth grade arithmetic." After the hearings, with the help of Richard Bradley, Brower continued to question the estimated evaporation rate at the proposed Echo Park Dam. In April 1954, three months after the hearings, Richard Bradley received a letter from Floyd Dominy, acting assistant commissioner of the Bureau of Reclamation, essentially stating that the Bureau had miscalculated the evaporation rate of alternative dam sites. ${ }^{27}$

The revised figures illustrated that the alternative option of a high dam at Glen Canyon was only a difference of 25,000 acre-feet per year. ${ }^{28}$ As a consequence of these revised figures, the Bureau of Reclamation was forced to change its argument for an Echo Park Dam from evaporation to hydroelectric power. ${ }^{29}$ Although the Colorado River Storage Project and the Echo Park Dam had the support of many Western congressmen, grave concerns about its three billion dollar price tag and the wisdom of adding more

\footnotetext{
${ }^{26}$ Harvey, Symbol of Wilderness, 147, 182-183.

${ }^{27}$ Harvey, Symbol of Wilderness, 192-201. Richard Bradley was one of Harold Bradley's seven sons, a Sierra Club member, and a physics professor at Cornell University.

${ }^{28}$ Harvey, Symbol of Wilderness, 201. The CRSP proposal that included dams at Echo Park and Split Mountain, and a low dam at Glen Canyon amounted to 621,000 acre feet of evaporation per year. The alternative proposal consisting of only a high dam at Glen Canyon amounted to 646, 000 acre feet per year. ${ }^{29}$ Harvey, Symbol of Wilderness, 218.
} 
irrigated farmland to a country already yielding an unhealthy agricultural surplus arose amongst many other members of Congress. ${ }^{30}$ These concerns, combined with the evergrowing voice of the conservationists, set the stage for a final congressional showdown in 1955-56.

At the same time that Brower was challenging the evaporation calculations of the Bureau of Reclamation and congressmen from around the country were having doubts over the cost and agricultural wisdom of the CRSP, the film Wilderness River Trail was being shown across the country. The Sierra Club "circulated the film among community organizations, garden clubs, and church and school groups in northern California, and, of course, among its own chapters .... By the first part of 1955, the film was available in nearly a dozen cities, including Chicago, Boston, Portland, Denver, New York, and Los Angeles." ${ }^{31}$ However, for David Brower one movie was not enough. Encouraged by the power of film to reach and influence an audience, Brower and Philip Hyde set off on the morning of May 15, 1955 to shoot footage for Two Yosemites. Believed by Brower to be the lowest budget film on record, Two Yosemites was shot in one day on five rolls of Kodachrome film for a total of five hundred dollars. Although only six copies were made, it was still shown "in a good many places." According to Brower, "It had quite an impact, showing what had been done to Hetch Hetchy, and all the claims that were made of how beautiful a lake it would be and how great a recreational resource. Of course it wasn't,

\footnotetext{
${ }^{30}$ Harvey, Symbol of Wilderness, 214-215.

${ }^{31}$ Harvey, Symbol of Wilderness, 237-38.
} 
and isn't; it wasn't necessary. The parallel with Dinosaur was so beautiful that we worked on that constantly." 32

The film's greatest influence may have been exerted on the hearts and minds of congressmen themselves. According to Mark W. T. Harvey,

Brower aimed the film at members of Congress, to remind them that the earlier battle had ended in tragedy and had caused anguish to John Muir during the last crusade of his life. Using still photographs of Hetch Hetchy Valley, taken early in the century, and contemporary pictures of its fluctuating reservoir, "Two Yosemites" sought to counter claims that Echo Park Dam would enhance the scenic backdrop by creating a beautiful lake. Hetch Hetchy Reservoir gave the lie to such claims, as the film revealed, with the raising and lowering of the water level leaving ugly mud flats around the rim. ${ }^{33}$

The great promoter of the film to Congress was Howard Zahniser. The tireless executive secretary of the Wilderness Society would wheel in a projector to the House Office Building, and as "he was opening it up, Congressmen would be so interested in the mechanics... they wouldn't resist it." In perhaps the most emotional viewing of the film, Congresswoman and Interior Committee member Gracie Pfost of Idaho was brought to tears. $^{34}$

On April 20, 1955 the United States Senate approved the CRSP bill including a dam at Echo Park, and attention turned to the House of Representatives. Opposition towards the Colorado River Storage Project and the Echo Park Dam was far greater in the House of Representatives thanks to the years of publicity work and letter writing campaigns spearheaded by conservationists. The lobbying bodies of the conservation organizations moved to oppose the entire CRSP. The move was just a tactic.

\footnotetext{
${ }^{32}$ David R. Brower, "Environmental Activist," 128; see also Kenneth Brower, interview by author, 27 November 2012.

${ }^{33}$ Harvey, Symbol of Wilderness, 238.

${ }^{34}$ David R. Brower, "Environmental Activist,”; see also David Brower, For Earth's Sake, 224-225.
} 
Conservationists had made it clear that as soon as Echo Park Dam was deleted from the proposed bill they would withdraw their opposition. Finally, in January 1956, Echo Park Dam was deleted from the bill, and the conservation lobby did withdraw its opposition. Passage quickly followed, and on April 11, 1956 President Eisenhower signed the bill into law. ${ }^{35}$

Passage of the Colorado River Storage Project without the Echo Park Dam was a landmark achievement for conservationists. Dinosaur National Monument was spared from the Bureau of Reclamation, and the Green and Yampa Rivers would remain free flowing through this majestic 200,000-acre preserve. Never before in conservation history had so many organizations joined together and pooled their resources over a conservation issue. Small conservation organizations such as the Sierra Club and Wilderness Society, large wildlife protection organizations like the Izaak Walton League and National Audubon Society, Garden and Women's clubs, and Civic Associations had come together to save a valued place. The great unity among these conservation organizations in their effort to preserve the sanctity of the national park system yielded a great deal of public support and created a legitimate political force to be reckoned with in the future. The conservationists' position and message gained strength largely through publicity. Using a combination of printed articles, books, and films, conservationists appealed effectively to the desire of the public. Americans responded by writing thousands of letters to their congressmen in favor of preserving Dinosaur National Monument.

${ }^{35}$ Harvey, Symbol of Wilderness, 268-285. 
The preservation of Dinosaur National Monument was the single most important conservation victory in the 1950s. It reaffirmed the sanctity of the national park system and laid the foundation for future battles regarding the preservation of nature. It contributed to the growth of the Sierra Club and the professional development of David Brower. In the North Cascades, David Brower and the Sierra Club would set a new conservationist agenda. They would advocate for a national park encompassing upper Lake Chelan, the Stehekin Valley, Eldorado Peaks, and Glacier Peak. Largely through the production of the film Wilderness Alps of Stehekin, David Brower's ideas would influence public opinion about the North Cascades for more than a decade. 


\section{Part 2: Wilderness Alps of Stehekin}

As the conflict over Dinosaur National Monument came to a close in early 1956, a controversy in the North Cascades began to intensify between those who wished to preserve its wild beauty and those who wished to extract its natural wealth. Although the conflict in the North Cascades was certainly not a repeat of the battle over Dinosaur National Monument, the controversy at Dinosaur did leave important legacies that would manifest themselves in the North Cascades campaign. The emergence of visual imagery, especially film, as a form of public persuasion was crucial in the campaign to save Dinosaur, and conservationists built upon its success with the production of Wilderness Alps of Stehekin.

\section{The Idea}

One day in the spring of 1956, Grant and Jane McConnell saw Charles Eggert's film Wilderness River Trail. Jane McConnell thought it would be a great idea for Eggert to make a film promoting the preservation of the North Cascades, and they went to him "in all innocence." Eggert told the McConnells that he would need eight thousand dollars to complete a film. Although it was much cheaper than the standard rate of the day (Grant McConnell estimated around thirty thousand dollars), it was still eight thousand more than the McConnells could spare. Initially disheartened, they brought the idea up with David Brower, who immediately agreed to support the film proposal. ${ }^{36}$ Since Brower had played a major role in Wilderness River Trail and Two Yosemites, it should come as no surprise that he liked the idea and helped push for some Sierra Club funding. Grant

\footnotetext{
${ }^{36}$ Grant McConnell, "Conservation and Politics,” 33.
} 
McConnell lobbied members through an "appraisal of the comparative value of still versus motion photography in telling the story of Glacier Peak." Ultimately, the Sierra Club provided five hundred dollars from its Conservation and Memorial Fund to help cover the costs of raw film. Nathan Clark volunteered to handle the filming in the North Cascades that summer. It was not nearly enough money to complete the film, but it was a start. More funding depended upon the success of the initial filming. ${ }^{37}$

Unfortunately, Nathan Clark's filming of the Glacier Peak area in the summer of 1956 resulted largely in failure. Clark shot the footage using Kodachrome film and then copied the footage onto additional Kodachrome film. ${ }^{38}$ The result was disastrous. As David Brower wrote in a letter to Chuck Hessey,

I would certainly vote against a kodachrome copy of a kodachrome copy. We lost more than $\$ 500$ dollars attempting that on our Wilderness Alps efforts. You will recall I could use only two shots by Nate Clark which had been so processed - the one of the cloud cap on Glacier Peak and the telephoto made of the north side of Glacier Peak near the end of the film. ${ }^{39}$

With an entire summer's footage essentially useless, the film project was off to an abysmal start. On top of discovering the loss of footage in the spring of 1957, Charles Eggert informed Brower that "even were the goose to lay the golden egg, this guy couldn't make that film for you. I'm just getting up after being two weeks flat on my back with Hepatitis, which puts me on the inactive list for a while - at least as far as drinking Harpers \& branch water and climbing mountains are concerned." ${ }^{40}$

\footnotetext{
${ }^{37}$ David Brower to Charlotte Mauk, 31 May 1956, SCOEDR, carton 23, folder 33.

${ }^{38}$ Nathan Clark to David Brower, 4 May 1957, SCOEDR, carton 23, folder 33. Eastman Kodack introduced Kodachrome film in 1935. This type of color film was difficult to process and needed professional level expertise.

${ }^{39}$ David Brower to Chuck Hessey, 16 December 1959, SCOEDR, carton 23, folder 33.

${ }^{40}$ Charles Eggert to David Brower, 13 August 1956, SCOEDR, box 3, folder 4.
} 
Thus, as the summer of 1957 approached, the film project focusing on Glacier Peak had squandered its preliminary budget and a summer's worth of footage, and the top choice for filmmaker, Charles Eggert, was recovering from hepatitis. The summer of 1956 had been Brower's opportunity to prove to other members in the Sierra Club that a movie in the North Cascades was worth finishing. The footage Nathan Clark had shot was going to be the leverage Brower would need to secure funding from the club for the project. With that footage rendered almost completely useless, the outlook for additional funding was grim. If a Sierra Club film about the North Cascades was to be made, something had to happen.

What happened was that Abigail Avery, a new member of the Sierra Club and a longtime member of the Appalachian Mountain Club based in Boston, Massachusetts, offered Brower a \$2,500 gift to help with the North Cascades film project. Avery, roommate of Jane McConnell at both Swarthmore and Yale Nursing School, had grown up camping and climbing in the White Mountains of New Hampshire with her father. First introduced to the North Cascades in 1940 on a climbing trip with the McConnells and her husband Stuart, Abigail would return to the North Cascades periodically after World War II and through her relationship with the McConnells develop an interest in the preservation of the area. ${ }^{41}$ Jane McConnell had told her "a film of the Chelan area would be a most constructive conservation step - if not the most." Abigail listened to Jane and in a letter to David Brower dated May 1, 1957 offered to gift an inheritance from a relative "who loved the out-of-doors." Abigail noted that the gift was "for the purpose of

\footnotetext{
${ }^{41}$ This group is credited with the first ascent of the east ridge of Mt. Buckner. See Abigail Avery, "Nurturing the Earth," 5; Fred Beckey, Cascade Alpine Guide: Climbing And High Routes, Vol. 2: Stevens Pass to Rainy Pass, $3^{\text {rd }}$ ed. (Seattle, The Mountaineers, 2003), 333.
} 
helping towards making such a film, if the time is right, and if you felt an A-1 job would

be done with available personnel." Even though $\$ 2,500$ was an incredibly substantial donation, Abigail realized it was likely not enough to cover the entire project, but she hoped it would inspire others to make donations to the project. ${ }^{42}$

Abigail's donation put the film back on track, and David Brower could hardly suppress his joy in his reply of May 10:

The sun has various ways of coming out from behind dark and troublesome clouds, and your letter of May 1 constitutes the brightest way I can recall in our North Cascades struggle. Your letter arrived just before the annual organization meeting of our Board of Directors and it was with enormous pleasure that I could tell them of your generous offer.

Abigail's donation allowed Brower to continue the project without depending on

additional funds from the club. As he writes in the next paragraph,

A critical need can now be met, a need that was quite beyond any resources we had in view. Our own film reserve fund has had too many demands upon it to begin to meet the need alone. But the little we have, plus the great deal you have made available, will get us well under way. We have an enviable list of volunteer experts whom we can exploit, so you may be assured that your gift will get the maximum possible mileage. And with your act as an example, we stand great likelihood of enlisting still further help when we reach the point of seeking the number of additional copies of the North Cascades film that the cause will undoubtedly need.

Given this unexpected second chance, David Brower decided to take matters into his own hands and shoot the footage for the film himself. He felt confident enough to write Abigail, "The time is ripe. I feel an A-1 job can be done." 43

\footnotetext{
${ }^{42}$ Abigail Avery to David Brower, 1 May 1957, SCOEDR, carton 23, folder 33; Abigail Avery, "Nurturing the Earth," 1-11; see also Grant McConnell, "Conservation and Politics," 33.

${ }^{43}$ David Brower to Abigail Avery, 10 May 1957, SCOEDR, carton 23, folder 33.
} 


\section{David Brower: Amateur Filmmaker}

David Brower began to acquire skill with the camera in 1936. As the new publicity manager for the Yosemite Park \& Curry Company, he learned the basics of cinematography from Clifford Nelson. He writes in his second autobiography,

From Cliff I learned some early rules about cinematography. Do not pan unless it is absolutely necessary, and then don't do it. The camera is supposed to photograph action, not be the actor. If, however, you insist on panning, do so to follow the action. If there is no action, pan only from left to right, the way your read, and start with a good composition, pause on a good composition, and end on one. ${ }^{44}$

The next year Brower shot his first film, entitled Fishing High, for the Yosemite Park \& Curry Company. Using the company's $16 \mathrm{~mm}$ camera, he captured footage of the High Sierra and composed the film's narration himself. One day when he was out shooting with the camera, he came across Walt Disney. Walt Disney loved the High Sierra and took the time to show young Brower how to reverse action by holding "the camera upside down when photographing the action" and splicing "the film right side up." It is not every day that a beginning cinematographer learns a thing or two from Walt Disney himself. Brower seemed destined to make films that made a difference. ${ }^{45}$

A more permanent influence on young David Brower's cinematic development was Ansel Adams. Three months after crossing paths with Adams while on a backpacking trip in the Sierra Nevada, Brower joined the Sierra Club "to read the Bulletin, climb rocks, and check out the unclimbed peaks of the Sierra Nevada." ${ }^{46}$ Aside from opening up more climbing opportunities for him, his membership in the Sierra Club led to a friendship between him and Adams. As Brower writes,

${ }^{44}$ Brower, Work in Progress, 44

${ }^{45}$ Brower, Work in Progress, 44.

${ }^{46}$ Brower For Earth's Sake, 187. 
My ability as a photographer inched slowly upward with Ansel's help... I found myself spending many an hour on many a day in Ansel's darkroom, watching him print, and listening to his advice. I learned about some essentials. What national parks were about... He led me to see what was behind and within a photograph... and what could happen when words and photographs worked their magic together. ${ }^{47}$

When Brower worked for the Park \& Curry Company, Adams even helped to develop his prints. As Kenneth Brower stated in an interview with the author, "So to have Ansel Adams, the greatest maestro of the darkroom ever to live, developing your prints, you learn stuff and he learned to compose and he learned how to go for emotional resonance in the image and he got some of that in those films." 48 The influence of Clifford Nelson, Walt Disney, and especially Ansel Adams had a profound impact on Brower's development as a filmmaker.

Brower's introduction to the power of film in helping to preserve an area came in 1939. Richard Leonard and Brower shot footage for Sky-Land Trails of the Kings. ${ }^{49}$ The film was shown "again and again all over California." It did not have a built-in sound track or narration, so Brower had to narrate the film separately and cue the music at the appropriate times. When he was not available to show the movie, the Sierra Club provided a copy of both the film and Brower's narration for others to use. Ultimately, Sky-Land Trails of the Kings helped preserve King's Canyon as a national park in $1940 .^{50}$

Brower made a ski mountaineering film called Skis to the Sky-Land in the winters of 1940-41 and 1941-42 but then would not be involved in another major film production until Wilderness River Trail. American involvement in World War II and Brower's

\footnotetext{
${ }^{47}$ Brower, For Earth's Sake, 188.

${ }^{48}$ Kenneth Brower, interview by author.

${ }^{49}$ Richard Leonard was a good friend of Brower's and another important member of the Sierra Club.

${ }^{50}$ Brower, Work in Progress, 45.
} 
service in the Tenth Mountain Division intervened. However, it was during his time as an instructor at the Seneca Assault Climbing School in West Virginia that Brower finally came to own his first movie camera. He bought his brother's camera and began filming the training at Seneca. He combined "new footage with the old... to entertain and educate the troops on... days when rain, snow, or sleet" forced them indoors. In this way, he was able to develop his cinematography skills. ${ }^{51}$ During the controversy over Dinosaur National Monument, Brower returned to the conservation arena and used his understanding of publicity and his skill with the camera to help preserve the monument through film. His creation of Two Yosemites in 1955 demonstrated that he possessed the requisite skill to take on a bigger film project. Nathan Clark's failure in 1956 and Abigail Avery's donation for a North Cascades film in May 1957 set the stage for his largest film project ever.

${ }^{51}$ Brower, Work In Progress, 46-47. 


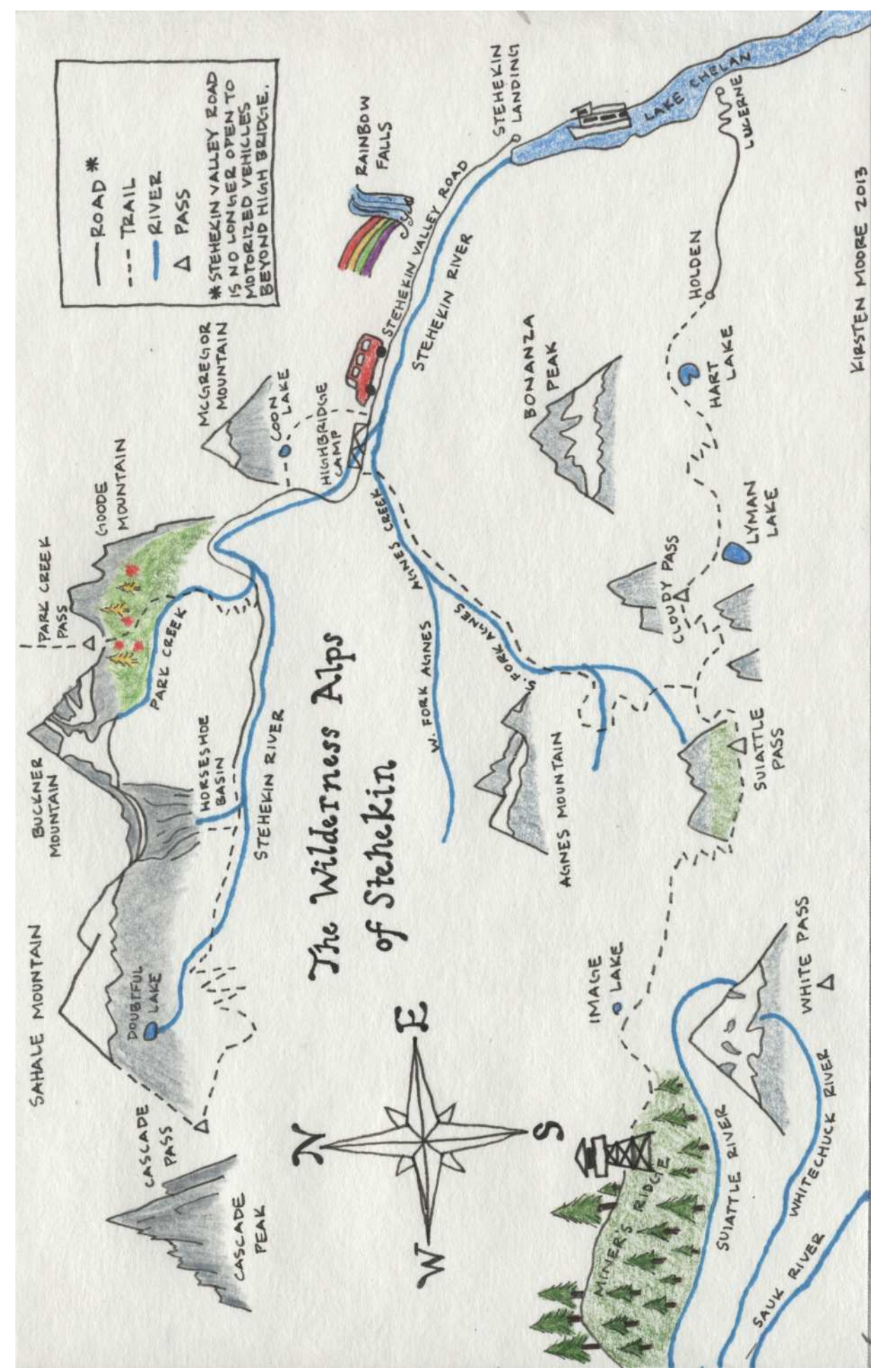

Figure 3. The Wilderness Alps of Stehekin. ${ }^{52}$

${ }^{52}$ Kirsten Moore, “The Wilderness Alps of Stehekin,” Map, 2013. 


\section{The Production}

The summer of 1957 was an exceptionally rainy one in the North Cascades. In addition to the Sierra Club trip already planned for the area that summer, Brower coordinated two trips into the mountains for filming. ${ }^{53}$ The first trip was to Cascade Pass, about twenty-five miles northwest of Stehekin. According to Grant McConnell, "Dave and Jane [McConnell], and our two kids, and Dave's boys went up to Cascade Pass, which is just an exquisite spot, with Ray Courtney. [Brower] was going to take pictures of the kids in the sun." Unfortunately for Brower and the rest of the party, the weather would not cooperate. They headed to Cascade Pass and "stayed for about a week. Dave would get pictures of dripping drops from the leaves, cloud mists swirling around. It was a miserable occasion, and it was generally regarded as a failure."54

Despite all of the failures so far, Brower refused to give up. Grant McConnell was back from his research trip to Oregon and accompanied the group on its second pack trip of the summer, this time up to Park Creek Pass. One of the most beautiful places in the North Cascades, Park Creek Pass is at the top of a hanging valley carpeted with alpine meadows. The embodiment of alpine wildness, the area just below the pass features prominently in the film thanks to "a little spate of nice weather" that allowed Brower to capture "an avalanche on Booker Mountain and kids picking huckleberries." ${ }^{\text {"55 Despite }}$ the atrocious weather, which Ann McConnell recalled as "the rainiest summer in twenty

\footnotetext{
${ }^{53}$ The Sierra Club had one "Base Camp" trip planned for the region in 1957. The trip took place from July 22 to August 3 in the greater Stehekin Valley. See "Base Camps," Sierra Club Bulletin 42, no 3 (1957): 19-26.

${ }^{54}$ McConnell, "Conservation and Politics" 33.

${ }^{55}$ McConnell, "Conservation and Politics" 33.
} 
years," Brower was finally able to capture some extended footage. ${ }^{56}$ When combined with the footage from Cascade Pass and a variety of other footage captured over the past few years, there was enough for Brower to make a film. ${ }^{57}$

Whether the film was going to be any good or not was an entirely different question. Brower seemed quite optimistic of the footage in a letter to Abigail Avery on September 18, 1957:

I promised I would let you know about our luck with the movies this summer. All the film has now come back from processing and I have a color work print of the best of it. All in all it looks as if we had enough light to get what we needed and have enough footage and coverage to go to town with. I hope you will agree when you get a chance to see the first rough draft. ${ }^{58}$

One person who remained skeptical was Grant McConnell. As he stated in an interview, "When we got back in the fall... I went up to his house, and he ran off five thousand feet of nothing; it looked like utter junk, just utter junk." When Grant expressed concern over the terrible state of the film, Brower responded, "You just wait. Just wait. I'm going to edit this." $" 59$

Brower and Charlie Eggert made quick work of editing, and Brower soon had a copy he was willing to show conservationists other than Grant McConnell. ${ }^{60}$ In a September 1957 gathering at Chuck Hessey's home in Naches, Washington, Polly Dyer,

\footnotetext{
${ }^{56}$ Ann McConnell, interview by author, 4 October 2012.

${ }^{57}$ In 1956 the Sierra Club took one "High Trip," one "Base Camp Trip," and one "Knapsack Trip" into the North Cascades. It was the first time the Sierra Club had conducted trips in the region. That summer's "High Trip" is of particular interest because footage from it appears in Wilderness Alps of Stehekin. It took place from August 24 to September 1 with a main camp near White Pass. See "About the '56 High Trips," Sierra Club Bulletin 41, no 3 (1956): 9-19. It is important to note that Brower did not originally intend for the White Pass footage to make it into the film. Nathan Clark's failure in 1956 and the terrible weather in 1957 forced Brower to find additional footage, which included scenes from White Pass, film Chuck Hessey donated, and aerial footage captured during a 1956 flight over the region.

${ }^{58}$ David Brower to Abigail Avery, 18 September 1957, SCOEDR, carton 78, folder 16.

${ }^{59}$ McConnell, "Conservation and Politics," 34.

${ }^{60}$ Brower, Work in Progress, 51.
} 
Chuck Hessey, and other Northwest conservationists saw the first cut of the film. ${ }^{61}$ Although not perfect, it was rounding into shape and would debut in its finished form on the evening of March 22, 1958 at the Second Northwest Wilderness Conference in Seattle. $^{62}$

It was an immediate hit, and the demand for its distribution was almost instantaneous. In a letter to Robert Golden of the Sierra Club dated March 31, 1958, Patrick Goldsworthy writes, "How soon can we have a copy of the Wilderness Alps of Stehekin? We need it now! I have two requests to show it already in Seattle and Mount Vernon.",63

Primarily thanks to the hard work, vision, and artistic skill of David Brower and the generosity of Abigail Avery, the final cut of the film was met with immediate delight. Although the project was steeped in early failure, it ultimately became a resounding success. Despite the Kodachrome debacle, Charlie Eggert's illness, funding difficulties, and atrocious weather conditions in the summer of 1957, Wilderness Alps of Stehekin aroused quite a positive response. As Grant McConnell states, "It came out beautiful, absolutely beautiful." ${ }^{\prime 4}$ The film would prove to be a powerful tool to conservationists over the next decade and would play an essential role in protecting the wildness of the North Cascades as a national park.

\footnotetext{
${ }^{61}$ Polly Dyer interview, "Preserving Washington Parklands and Wilderness," 35-36.

${ }^{62}$ NCCC News 2, no. 4 (1958)

${ }^{63}$ Patrick Goldsworthy to Robert Golden, 31 March 1958, NCCCR, box 1, folder: "Miscellaneous Jan-July 1958."

${ }^{64}$ McConnell, "Conservation and Politics," 34.
} 


\section{The Content}

At thirty-one minutes, Wilderness Alps of Stehekin is twenty minutes longer than Brower's Two Yosemites. The film opens with waves gently rolling into the Washington shore. As the end of "America the Beautiful" plays faintly in the background, Brower uses the ocean as a powerful symbol of wildness. In a sentence illustrating mankind's recent understanding of its abuse of the world's oceans, Brower states, "The wild, shining sea, shaping the earth through the ages, never the same, yet not to be changed by man, who long ago learned to accept it for what it is-even as we are now learning not to change some of the wild land, but to keep it natural, to seek from it answers to questions we may yet learn how to ask."65

After forty-five seconds the movie transitions to three quick shots of the Cascades before shifting to Washington State's two national parks-Mt. Rainier and Olympic. Brower's brief inclusion of these parks is a strategic move to associate preservation of the North Cascades with the national park system. Although he is careful to use neutral language to keep the film clear of an overt political agenda, Brower does highlight the virtue of protecting wild lands in a national park when discussing the Olympic rainforest: "Scores of centuries built this, the Olympic rain forest, a cool green world, hushed as a prayer. Man could wipe it out in a decade. Instead, two decades ago, he consecrated it as a park, not to be impaired, a place where all generations could come to know the dignity of nature." ${ }^{66}$ Brower's praise of the park system for preserving the wildness of the Olympic rainforest is reinforced in the next few scenes.

\footnotetext{
${ }^{65}$ David R. Brower, "Wilderness Alps of Stehekin,” The Living Wilderness 58, no. 66 (1958): 18.

${ }^{66}$ Brower, "Wilderness Alps," 18.
} 
After the rainforest, the film moves on to quick but beautiful glimpses of Yosemite Valley, Grand Canyon, and Dinosaur National Monument, which are all included in the national park system. As the images flow, Brower focuses on the importance of people in preserving these areas:

This for all people thanks to the vision of people-people who nearly a century ago made Yosemite the first park to be reserved for the nation and the world... In mid-century the wilderness river trail of Dinosaur's Echo Park country was in danger until Congress reassured its safety. The people appreciated it in the nick of time. ${ }^{67}$

Brower's emphasis on the importance of the role of people in general and certain individuals in particular in preserving these landscapes is magnified when he comments on Monument Valley, which still was without adequate scenic resource protection:

Such places belong to our national gallery; they are the last of our primeval landscapes, the few surviving samples of a natural world, to walk in, to see, to listen to, to feel the mood of, to comprehend, to care about. There isn't much left of it. What there is is all all men will ever have, and all their children. It is only as safe as people, knowing about it, want it to be. $^{68}$

As Brower finishes this part of the narration, the film moves seamlessly from Monument Valley to the North Cascades and Lake Chelan.

In the first four minutes, Brower manages to accomplish two important tasks.

First, he alerts the viewer to the relationship between preservation and the national park system. Brower rather subtly underscores the argument that in the case of the North Cascades the national park system would best accomplish protection of its wild and scenic lands. Second, Brower emphasizes the important role that "people" have in protecting these areas "unimpaired" for the good of those to come. In this way, he sets the

\footnotetext{
${ }^{67}$ Brower, "Wilderness Alps," 18.

${ }^{68}$ Brower, "Wilderness Alps," 18.
} 
tone and underlying message of the film even before showing any substantial content of its main subject— the North Cascades of Washington State.

Finally, after four minutes and fifteen seconds, the North Cascades make their entrance. For the next two and a half minutes the film shows aerial footage of the region. As grand images of Lake Chelan, mountain peaks covered in glaciers, and vast forested valleys stream across the screen and Clair Leonard's forceful pipe organ music eliminates any hope of reverie, Brower focuses on explaining to the viewers "the conflict":

In the Northern Cascades, back of Lake Chelan there is alpine wilderness that belongs to our national gallery too... a conflict between those who wanted to use raw materials and those who wanted to preserve natural beauty... We knew it was great country. We also saw that its size alone could not protect it.

Images of clear-cutting in the White Chuck Valley and the abandoned mining town of Holden on the west side of Lake Chelan provide stark contrast to the preceding scenery, as does the narration:

On the west side men were already clear-cutting the last virgin forests... Crossing Cascade Pass, in the heart of the wilderness, we were but a few minutes from other wild forests, also wanted for their timber... we flew over a clump of buildings of a mining town, deserted now, the ore played out. The people moved away in a matter of weeks; their marks will be there for centuries. This had happened here. It could happen in many other parts of the Cascades. Would America have to go without much to leave its forest wilderness unspoiled? ${ }^{69}$

In seven short minutes, Brower has explained the conflict, captured the interest of the viewer, and set the agenda. The remaining twenty-four minutes follow a cast of characters through the landscape of the North Cascades in an attempt to show (and tell) the viewer what the North Cascades have to offer.

${ }^{69}$ Brower, "Wilderness Alps," 19. 
Wilderness Alps of Stehekin captures the experience of a number of people in their enjoyment of the North Cascades. Brower's two oldest sons, Ken and Bob, who were twelve and eleven years of age respectively at the time, are usually seen walking about the landscape ${ }^{70}$ As Ken recalls, "We were mostly in these pictures for scale and because we were cute little kids.... We would grumble and gripe. But he was persuasive and we'd always do it. We never had a sit down strike or anything. We got drafted as little actors in these movies." ${ }^{, 71}$ Actors such as Ken and Bob certainly did have an important cinematographic effect in providing scale to the vastness of the North Cascades. The children proved that the terrain was accessible to all who were able and willing to strap on their hiking shoes or mount their horse and head for the trails. Most importantly, the children represented the "future generations."

After seven minutes, the film takes the viewer by boat, jeep, horse, and foot into the heart of the North Cascades. The Browers board the Lady of the Lake in Chelan and make the four-hour trip northwest up Lake Chelan to the village of Stehekin. Brower highlights the beauty of the lake and underscores its dramatic nature in the narration: "A deep fiord, floating 1,500 feet above the canyon's floor, a floor that is well below sea level and 9,000 feet below the high peaks of the upper end-America's deepest canyon." 72 In Stehekin, he and his two boys hop into a jeep and drive along an old mining road that follows the Stehekin River into the backcountry. Brower idealizes this road for about a minute and a half. His emphasis of the road helps to highlight the recreational

\footnotetext{
${ }^{70}$ Kenneth Brower's birth date is November 15, 1944; Robert's is July 6, 1946.

${ }^{71}$ Kenneth Brower, interview by author.

${ }^{72}$ Lake Chelan (1,486') is the third deepest lake in the United States after Crater Lake in Oregon $(1,949$ ') and Lake Tahoe in California (1,645'); Brower, "Wilderness Alps," 19.
} 
accessibility of the area and argues that paved roads are not necessary in wild areas. ${ }^{73} \mathrm{He}$ romanticizes the road in lyrical prose characteristic of his narration:

The road starts at a handsome lakeshore and deadends in paradise. It connects with no highways and doesn't compete with any. The few cars on it know each other by their first names. It is seldom far from the river, and if you stop for a close look, no horn blows behind you. Great trees tower over the road. Flowers and grass grow alongside it and between the wheeltracks. It's bumpy enough to slow you down to see the roadside. It doesn't cut in and shoulder its way through. It treads softly, in no hurry to someplace else; it's there already. ${ }^{74}$

The Browers stop ten miles up the road from Stehekin at a place called High

Bridge. There they meet Chuck and Marian Hessey, who make their first appearance in the film. Chuck Hessey is a notable figure in the North Cascades struggle. As an important member of the North Cascades Conservation Council and a filmmaker himself, he provides several minutes of footage for Wilderness Alps of Stehekin taken with his own camera. ${ }^{75}$ Offering images of the North Cascades, including alpine meadows and peaks, wildlife such as mountain goats and ptarmigans, and ski touring scenes showing the landscape covered in snow, the Hessey footage nicely complements what Brower is able to shoot.

\footnotetext{
${ }^{73}$ In the 1930s the Park Service began improvements on the old Tioga Road in Yosemite National Park. The improvements aimed at transforming the tortuous dirt road into a highway capable of accommodating fast moving automobiles through the eastern portion of the park. As the project entered its final phases in the late 1940s and early 1950s, Harold Bradley, David Brower, and Ansel Adams opposed the project's proposed construction through the Tenaya Lake area. Bradley and company cherished the wildness and undeveloped nature of the region and feared increased automobile traffic and development the improved highway was sure to bring. See Cohen, History of the Sierra Club, 93-100, 134-139.

${ }^{74}$ Brower, "Wilderness Alps," 20.

${ }^{75}$ Chuck Hessey made two films on the North Cascades: Glacier Peak Holliday and Skiing in the Winter Cascades. Glacier Peak Holiday was the more popular of the two, but even this film paled in comparison to the popularity of Wilderness Alps of Stehekin. Only a few copies of Glacier Peak Holiday were ever produced and distributed. According to film statistics from the Conservation Film Center for the years 1964-1968, 1 copy of Glacier Peak Holiday was shown 27 times to 1325 people. During the same period, 9 copies of Wilderness Alps of Stehekin were shown 498 times to 29,617 people. I am not aware of any copies of Glacier Peak Wilderness other than the one the NCCC distributed and those in Chuck Hessey's personal collection.
} 
After the Hesseys quietly make their exit in the fourteenth minute, the film backtracks geographically to Rainbow Falls and Coon Lake near Stehekin before heading in the direction of High Bridge to the Agnes Creek Valley. Brower adroitly facilitates this transition in the narration through the storyline that he and his boys must "wake up" their “walking muscles." Having shown the Hesseys' footage of remote areas of the North Cascades, Brower demonstrates how areas like Rainbow Falls and Coon Lake offer a more accessible recreational experience without forfeiting scenic beauty. Once their walking muscles are warm, the film moves to Agnes Creek Valley.

Arguably the most important place in the story of North Cascades conservation, the Agnes Creek Valley stretches northward from Suiattle Pass to the Stehekin River. The verdant valley is home to some of the largest cedars in northern Washington. Boasting trees with diameters sometimes exceeding ten feet, the Agnes Creek Valley became the target of a proposed timber sale in $1955 .^{76}$ It was word of this timber sale that prompted Grant McConnell to take an active role in the preservation and ultimately brought the area to the attention of David Brower and other conservationists. The film devotes only thirty seconds to the lower Agnes Creek Valley and does not venture into the heart of the forest where the largest trees are. As Brower states in the film, "We only had time that day to explore the Agnes trail for a mile or two, to see what a wilderness forest is like when man leaves it to its own wondrous devices." ${ }^{, 77}$ Brower misses an opportunity in this

\footnotetext{
${ }^{76}$ The primary purchaser of timber from the Stehekin Valley was the Chelan Box and Manufacturing Company located in Chelan, WA. George Wall, the company's president, worked hard to convince the Forest Service to decrease the size of its proposed Glacier Peak Wilderness Area. Wall and many members of Washington State's timber industry believed that harvesting the forests around Glacier Peak was necessary to sustain local economies. See Marsh, Drawing Lines, 44.

${ }^{77}$ Brower, "Wilderness Alps," 21; Although Brower misses the large old growth of the Agnes Creek Valley, he does include a shot of large Western Red Cedars in the Sauk River Valley towards the end of the film.
} 
scene to showcase the sheer immensity of the Agnes old growth. As Polly Dyer critiques, "I remember one of my own personal recollections was that it was emphasizing too much high country, because the forest is where your big argument is in trying to get things protected. The film didn't have enough forest in it." Although it would have taken several more hours of hiking to reach the largest trees farther up the valley, the immensity and majesty of these trees surely would have made a more powerful image than the shots of waist-high ferns. ${ }^{78}$

In Brower's narration of the Agnes Creek Valley, he touches very briefly on a concept conservationists would place great value on in the coming years. As the film shows a distant image of the Agnes Creek Valley, Brower mentions the value of the valley as a "corridor into the great Agnes country and its big glacier basins." Preservation advocates in the North Cascades believed in the importance of keeping river valleys forested and free from roads not only for the scenic beauty the trees provided but also because they protected the high country from becoming too accessible. ${ }^{79}$

But Brower knows that some roads must be: "Then another day, with a late breakfast in Stehekin, and lunch in our pockets, we went on a walk into Horseshoe Basin, to sample its high gardens and friendly places." Horseshoe Basin is located not far from the end of the Stehekin Valley Road. That one can leave in late morning from Stehekin and still have time to enjoy the wonderful alpine meadows in Horseshoe Basin underscores the accessibility of these wild lands for many travelers. Brower spends about a minute following Ken and Bob around Horseshoe Basin. The combination of beautiful

\footnotetext{
${ }^{78}$ Dyer, "Preserving Washington," 35-36.

${ }^{79}$ Brower, "Wilderness Alps," 21.
} 
alpine flowers and the seemingly ever-present rugged peaks of the region dominates the landscape.

The film then transitions into a two-minute sequence which celebrates the beauty of summer rain showers in the mountains. Finally able to make use of some rain footage, Brower shows the beginning of a storm by focusing on a pond and capturing the raindrops wrinkling its surface. Then follow simple shots of nature-a twig, pine needles, pink mountain heather-and more complex ones of misty peaks and one of the boys walking through alpine meadows. The real mastery of this sequence is not so much in the images as in the narration

The northern traveler is seldom bored by blue skies. But then, monotonous fair weather can't build mountains like these, and their glaciers and forests and flowers. We liked the way the mountains looked and discovered how to like what made them that way-don't scurry for cover and miss the show-stay out and be part of it... We got our feet squished a little in our boots. But what never gets wet can never get dry. We got both. We never came back from one of our walks wishing we hadn't gone out, and we never came back feeling only half alive. I guess the boys knew it all the time, and I rediscovered it—epidermis is waterproof! And the rain is only water. And that strange tingling - that was just my circulation circulating! I had almost forgotten the feeling. ${ }^{80}$

Brower's gift for filmmaking was not limited to the camera and the editing machine. His real talent was his ability to construct a lyrical narration that complemented the visual footage and added a dimension of humor and fun. According to Kenneth Brower, the phrase "The northern traveler is seldom bored by blue skies" became part of the Brower offspring's vocabulary. When the Browers were in the mountains and it started to rain, they often recited that line in a playful and sarcastic manner. Kenneth Brower believed it was very effective in the film: "It was a good line because it was a

80 “Brower, "Wilderness Alps," 21-22. 
playful line. There is an interesting humor in the line... on one level it's poking fun at its own rationalization in a very subtle way, but in another [way] he really meant it." In other words, of course hikers in the North Cascades are not bored by blue skies because it rains so much, but at the same time storms are beautiful in their own right. Kenneth goes on to say, "He was schooled by Ansel Adams, who loved clouds and big dramatic moody thunderstorms. That was sort of Ansel's signature as much as anything. So he had an esthetic appreciation for big, dark, rainy, impressive skies. ${ }^{81}$ Brower's humor was his own, but Adams sharpened his eyesight.

Two other memorable phrases from this scene provide the same combination of wit and humor: "Epidermis is waterproof" and "But what never gets wet can never get dry," and they also made the children's phrase book. To Kenneth Brower they are so important because "they're not the kind of lines that were often in that kind of movie. Not in this kind of argumentative movie; this tendentious sort of movie that's trying to argue for wilderness... The typical sort of narrative in a lot of documentaries doesn't have very much fun, and I think he did [put fun in it]." ${ }^{, 82}$

Brower also managed to combine some physical humor with verbal humor in the next few scenes. After the storm sequence, the focus shifts to a group embarking on a pack trip up to Park Creek Pass. Ken and Bob are still present, but three new people enter into the story-Ray Courtney, Grant McConnell, and most importantly Ann McConnell. Ann McConnell, Grant McConnell's ten-year old daughter, gave Brower an opportunity to create a humorous sub-storyline of pre-teen boy-girl interaction: "You know about preteenagers. How does a girl break the barrier, with men interested only in practical things?

${ }^{81}$ Kenneth Brower, interview by author.

${ }^{82}$ Kenneth Brower, interview by author. 
Well, anyway you can get a horse's attention.... In its own quiet way the thaw begins, the slow thaw." 83 The narration complements footage of awkward interaction (or noninteraction) between the boys and Ann.

The next minute follows the group on horses on the trail up to Park Creek Pass. The first scenes show the group well below treeline as it rides along the river. Soon the high peaks and glaciers come into view, as the riders climb towards the pass. When the group stops for the night, Brower once again creates a humorous short storyline between the boys and Ann: "Unpacking can be hard work, so the boys rested, but not Anne [sic]. She got her kitchen appliances ready_-whereupon the boys decided to help her bring in the squawwood so we could get a fire started." The actual footage shows a humorous shot of the boys exhausted on the ground and Ann building a fire ring ("kitchen appliances") with some rocks. As the group prepares for dinner, Brower stages a shot of Grant throwing food this way and that in search of where the soup was packed. As the group sits around the fire eating, Brower includes yet another humorous line that follows the pattern Kenneth Brower underscores: "Never mind what the cook has mixed up. If it doesn't look too fancy, wait until it gets dark and you won't have to see what you're eating." 84

The next three minutes follow Ken, Bob, and Ann as they explore the area around Park Creek Pass. The camera captures the children walking off trail around tarns, across alpine meadows filled with heather, and scrambling up rock outcroppings to spectacular views. After including a marmot and a grouse, the film moves to its most humorous scene. As Kenneth Brower recalls, this was "always the sequence the little old ladies

\footnotetext{
${ }^{83}$ Brower, "Wilderness Alps," 22.

${ }^{84}$ Brower, "Wilderness Alps," 22.
} 
loved." ${ }^{85}$ The group found a huckleberry patch, which Brower describes as "the biggest you ever saw, the bushes loaded with them, dark-ripe and juicy, each tasting good as a huckleberry should, and as only a fresh wild ripe colossal huckleberry can." ${ }^{\text {} 86}$ As Bob and Ann quickly pluck huckleberries into their mouths, the film shows Ken collecting huckleberries in a Sierra Club cup. He then stands up and walks over to Ann and gives her the cup half-full with berries. She accepts, but before Ken leaves he grabs a handful of berries and runs off.

This scene greatly annoyed Kenneth Brower and to a certain extent Ann

McConnell. It bothered Kenneth a great deal because, as he recalls,

It was something I would never do in real life. I would eat it myself when I was ten [twelve] years old. I wouldn't give it to a girl... So he said 'just give it to her it'll be a nice thing and then just after you about give it to her think about it again and kind of take it back and take some of the berries out of it.' It was completely staged and it was nothing I would have ever done. I was embarrassed to do it. I was a shy kid. It was corny. But I did it. $^{87}$

Ann recalls, "We had no idea... his [David Brower's] little thing that I was having some sort of romance with the Brower boys that was completely made up after the fact.... He said I want you to walk there. I want you to pick huckleberries and give them to each other. We didn't know the plot; we probably wouldn't have participated if we had." 88

Reversing the sequence in which the filming occurred, the group then heads towards Cascade Pass. This scene is important because it is the first time the west side of the Cascades receives sustained attention. ${ }^{89}$ As Brower narrates,

\footnotetext{
${ }^{85}$ Kenneth Brower, interview by author.

${ }^{86}$ Brower, "Wilderness Alps," 22.

${ }^{87}$ Kenneth Brower, interview by author.

${ }^{88}$ Ann McConnell, interview by author.

${ }^{89}$ During the aerial footage, the film briefly shows west side clear cuts.
} 
Cascade Pass, deep in the heart of the little-known alps of the North Cascade, seemingly remote-yet here we met at noon a friend who had left New York City late the night before, a whole continent away! We crossed the Pass itself on foot and looked west toward El Dorado and the Cascade River Canyon. Our friend had come up this canyon one of the west-side avenues into the mountains, like the Whitechuck [sic] and Suiattle. $^{90}$

The preservation of the west side river corridors into the North Cascades was a major concern for conservationists. In the same way as it was imperative to protect the Agnes Creek Valley, conservationists believed that Glacier Peak and the Eldorado Peaks areas could not receive proper protection unless the corridors leading into them were also protected. Aside from the importance of preserving the west side river valleys, Brower once again uses this sequence to highlight the accessibility of this remote area. He underscores the point that one could be in New York City one day and in the heart of the North Cascades the next. Although the scenic beauty of the North Cascades may seem distant, Brower illustrates that it is not as far away as one may think and that it is possible to visit this area from across the country.

Brower hammers home the theme of accessibility in the film's penultimate sequence, which features a Sierra Club High Trip camped near White Pass on the south side of Glacier Peak. The scene shows a diverse group consisting of both young and old. Brower's two youngest children, Barbara (6) and Johnny (3), make cameo appearances and are contrasted against older folks enjoying the beauty of the high country. ${ }^{91} \mathrm{He}$ narrates, "From our camp everybody explored the alps, poked along the parklike high

\footnotetext{
${ }^{90}$ Brower, "Wilderness Alps," 22.

${ }^{91}$ Howard Zahniser, executive secretary of the Wilderness Society, is one of the older folks in this scene. Zahniser was an advocate of wilderness areas and championed a national wilderness preservation system. His efforts helped lead to the passage of the Wilderenss Act of 1964, which added the Glacier Peak Wilderness Area to the national wilderness preservation system. For more on Zahniser's importance to conservation see Mark Harvey, Wilderness Forever: Howard Zahniser and the Path to the Wilderness Act (Seattle: University of Washington Press, 2005).
} 
trails, wandered through the miles of grasslands, let the mountain wind blow away flatland cares. Almost everybody got out on a glacier, too-the Whitechuck [sic] Glacier's flat icefield is made to order for beginners. ${ }^{, 92}$ As the sequence comes to a close, it seamlessly transitions from a theme of accessibility to the reason for preserving the area—-the magnificent grandeur and beauty of Glacier Peak. One shot from the south and one from the north let the viewer appreciate Glacier Peak for twenty seconds. ${ }^{93}$

The concluding sequence takes the viewer back to Lake Chelan and the Washington coast. As "America the Beautiful" plays in the background, Brower once again emphasizes the importance of keeping the North Cascades wild:

The sun would light all this mountain land soon, and we hope it will always reveal wilderness there-in the avenues of unspoiled forest, in the flashing waters of the sidestreams and the river, in the friendly lower gardens and grassy alplands, up at timberline and in tundra, on the glaciers and peaks. Other people will want to be walking our trails, up where the tree reaches high for the cloud, where the flower takes the summer wind with beauty, and the summer rain, too. They will want to discover for themselves the wildness that the ages have made perfect. They have a right to discover wild places like these, I told Ken and Bob, just as we did-and your children and theirs too. They can discover them, but only if we keep some wildness in between the shining seas; only if man remembers, in his rising tide, not to engulf his last islands of wilderness. ${ }^{94}$

Although the images and the narration are powerful parts of the film, its

soundtrack—featuring the Obernkirchen Children's Choir—plays a crucial role in setting the mood and tone. "America the Beautiful" and "The Happy Wanderer" are both vocal selections from this choir. "America the Beautiful" is a fitting selection for both the opening and closing scenes, and "The Happy Wanderer" enhances the spirit of adventure,

\footnotetext{
92 Brower, "Wilderness Alps," 23.

${ }^{93}$ Nathan Clark took the northern shot from Image Lake using a telephoto lens in the summer of 1956. It was one of two shots usable from his filming that summer.

${ }^{94}$ Brower, "Wilderness Alps," 24.
} 
alpine quality, and scenic grandeur present throughout. Clair Leonard's organ music provides a contrast to the upbeat melody of "The Happy Wanderer." Originally performed on the pipe organ at Bard College's chapel for Charles Eggert's film "A Canyon Voyage," Leonard allowed Brower to use this music for Wilderness Alps of Stehekin. However, its inclusion was not guaranteed in the winter of 1958. In a letter to David Brower on February 6, 1958, Eggert writes, "I thought all the rest of the day, after your phone call, attempting to come to a clear and honest answer to our wanting to use the Canyon Voyage music for your new film. Now there isn't one single objection to your using it except one.... I don't want you to. Why? Pure selfishness.” Eggert and Brower did work out a special arrangement, and when the movie premiered the next month, Clair Leonard's organ music was part of it. ${ }^{95}$

The filming and production of Wilderness Alps of Stehekin faced many challenges. Brower overcame funding shortages, botched film copying, atrocious weather, and soundtrack obstacles in order to produce a film advocating scenic preservation of the North Cascades. Although just an amateur filmmaker, he displayed an exceptional talent for filming and composition. Building on twenty years of filming experience, he blended a storyline featuring children and adventure with shots of alpine grandeur. When combined with a complementary soundtrack and a witty, descriptive narration, the footage became a film that helped change the history of Washington's North Cascades. As Ann McConnell recalled, "It was the force that created the park." "96

\footnotetext{
${ }^{95}$ Charles Eggert to David Brower, 6 February 1958, SCOEDR, box 3, folder 4; David Brower to Mrs. Richard A. Holberg, 25 August 1958, SCOEDR, carton 23, folder 33.

${ }^{96}$ Ann McConnell, interview by author.
} 
The film highlighted Lake Chelan, the Stehekin River Valley, and Glacier Peak and delicately advocated for preservation of the area as a national park. However, when the film premiered in March 1958, conservationists were not united around this idea. Many conservationists felt that Brower's film focused too much on preserving the east side of the North Cascades and not enough on the west side. Moreover, conservationists disagreed on whether the United States Forest Service or the National Park Service would be the best custodial agent for the land and the most apt to preserve its qualities of wildness. In the first few months after its premiere, Wilderness Alps of Stehekin would play an important role in uniting conservationists and establishing a conservation agenda that focused on the areas emphasized in the film. 


\section{Part 3: A National Park for the North Cascades?}

On March 22, 1958 Wilderness Alps of Stehekin premiered to a conservationist audience at the Second Northwest Wilderness Conference. The film played an important role in articulating the pro-national park position of activists such as David Brower, Grant McConnell, and David Simons. Moreover, it helped to show conservationists who were ambivalent about the North Cascades controversy that this was one of the primary issues of the time and deserved their attention and support. Over its first six months, the film proved to be an important tool for helping to unite conservationists around the national park idea. A brief written by David Simons, entitled "The Need for Scenic Resource Conservation in the Northern Cascades of Washington," served as a written counterpart to Wilderness Alps of Stehekin. The brief outlined specifically the need for a national park in the North Cascades and established a proposal for the park boundaries. Released on June 4, 1958, the brief was essential in changing the position of many Seattle-based conservationists.

Originally no one connected with the movement had favored a national park solution for the North Cascades. Brower, McConnell, and Simons were among the first to switch their views. ${ }^{97}$ David Simons, a student at the University of California, spent two summers conducting a scenic resource review of the area and concluded that a national

\footnotetext{
${ }^{97}$ John B. Oakes "Conservation: Program to Save the Wilds." New York Times (1923-Current File), May 05, 1957. http://search.proquest.com/docview/113984140?accountid=13265. In this edition of his monthly conservation column in the New York Times, Oakes makes the first public appeal for a postwar national park in the North Cascades. Specifically, Oakes states that "Such a region as the Cascades wilderness in northwest Washington, 'unquestionably qualified for national park status,' is being studied by the Forest Service with an eye to wilderness preservation, but what this incomparable region really needs is permanent protection in its entirety as a national park." Oakes's brief suggestion comes a full ten months before the premiere of Wilderness Alps of Stehekin. Despite Oakes's suggestion for a national park in May 1957, the first sustained attempts at promoting a postwar national park are in Wilderness Alps of Stehekin and Simons's brief.
} 
park would provide the best protection. Who convinced whom is a murky proposition to untangle, but it is logical to assume that the three men influenced each other. Each of them would come to support a national park in the North Cascades and work hard to convince other conservationists. ${ }^{98}$

\section{Grant McConnell: Voice of Stehekin}

The story of the national park for the North Cascades in many ways begins with Grant McConnell, who was born in Portland, Oregon in 1915. When he was fifteen, his father introduced him to the world of mountaineering. They climbed Mount Hood, Oregon's highest peak, and McConnell "never recovered from it." Over the next seven years he spent much of his free time climbing mountains. As McConnell entered Reed College, he began searching for new mountains to climb in the Pacific Northwest and discovered that "up in the north there was a blank spot on the map, with virtually no roads or place names." He visited Lake Chelan and the North Cascades for the first time in 1937 and fell in love with them. He returned three years later with his wife Jane and some friends. They made a first ascent of Devore Peak and an impressive twenty-two hour traverse of Mount Buckner. ${ }^{99}$

McConnell served in the Navy during the latter part of World War II and was stationed in the Pacific. During this time, he and Jane decided to look for a place in Stehekin. After some effort and swapping, Jane secured a cabin and some land at the end

${ }^{98}$ See Michael P. Cohen, History of the Sierra Club, 220-228. Cohen argues that David Simons is the key force behind the change to a national park and claims (I believe unwisely) that there was a quid pro quo between Simons and Brower. Essentially, Cohen argues that Brower convinced Simons that a wilderness bill was a good idea, and in exchange Brower supported "Simons' park plans with more energy." Cohen ignores the impact of the Three Sisters controversy on Brower's thinking and McConnell's extremely low opinion of the Forest Service.

${ }^{99}$ Grant McConnell, "Conservation and Politics," 1-2. 
of Company Creek Road, seven miles from Stehekin Landing. They spent a month at the cabin in May 1945 and then became year-round residents of the valley that December. They spent three years in Stehekin, living the simple life and starting a family. ${ }^{100}$ For financial reasons the McConnells eventually moved to Berkeley so Grant could finish his graduate work. $^{101}$

Grant McConnell developed an appreciation for Stehekin as a place, but conservation issues were of no concern to him in the late 1940s. He paid no heed to the Howe Sound Company mining operation at Holden and even wrote a letter to the Forest Service in 1947 advocating a small-scale timber sale on behalf of his neighbors, the Courtneys. It was not until the 1950s that he began to develop a preservation ethic. After publishing his dissertation and subsequently being hired to the Berkeley faculty, he looked for a new topic to research. Interested by the controversy over Dinosaur National Monument, he decided "to examine the set of ideas that were at issue." 102 The result was an article entitled "The Conservation Movement_-Past and Present," published in the September 1954 issue of Western Political Quarterly.

If Grant McConnell was not conscious of conservation before the article, he certainly became so afterwards. Returning to Stehekin in the summer of 1955, he heard rumors of potential Forest Service timber sales. As historian Kevin Marsh writes, "the thought of logging roads and clear-cuts in the Agnes Creek valley horrified him." "103 While McConnell was searching for likeminded support, three active members in the

\footnotetext{
${ }^{100}$ Grant McConnell's book Stehekin: A Valley in Time shares some of their experiences and stories as fulltime residents in Stehekin.

${ }^{101}$ Grant McConnell, "Conservation and Politics," 2-6.

102 McConnell, "Conservation and Politics," 5-7; see also Manning, Wilderness Alps, 85-86.

${ }^{103}$ Marsh, Drawing Lines, 41-42.
} 
Mountaineers Conservation Committee (Seattle, WA)—Polly Dyer, Phil Zalesky, Laura Zalesky—passed through Stehekin on a conservation scouting mission. In a coincidence now legendary, Jane McConnell saw three ice axes attached to packs outside the restaurant at Stehekin Landing and hurried in to find the owners. Inquiring about what peaks the three had climbed, she instead found out they were "getting a firsthand feel for the forested valleys threatened by logging and for alpine meadows under assault by miners to the east and north of Glacier Peak." Jane responded, "You have to meet Grant! He's trying to stop logging in the Agnes and Stehekin Valleys."' Unfortunately, the three had to catch the ferry, and it would not be until the fall that Polly Dyer would swing by and meet Grant McConnell while passing through Berkeley. ${ }^{104}$

As the preservation of the North Cascades became a growing issue in the second half of the 1950s, Grant McConnell realized the importance of a strong conservation front and believed that the film Wilderness Alps of Stehekin was the key to uniting conservationists in a common agenda for protecting the North Cascades. Specifically, McConnell wrote in early 1958 that "the problem of first priority remains what it has been from the beginning - to convince the conservationists themselves on the singular values of the North Cascades, on the size of the area that needs to be taken into account and on the necessity of the national park solution." McConnell understood that preservation of the North Cascades would go nowhere unless conservationists across the country understood the unique beauty of the area and the need to preserve it as a national park. $^{105}$

\footnotetext{
${ }^{104}$ Polly Dyer Introduction to Grant McConnell, "Conservation and Politics," i-ii. See also Manning, Wilderness Alps, 93-4 and Marsh, Drawing Lines, 42.

${ }^{105}$ Grant McConnell to David Brower, 28 February 1958, SCOEDR, box 6, folder 11.
} 
Frustrated by the "apathy, defeatism and stupidity among some of our friends,"

McConnell lashed out against many conservation organizations in a letter to David

Brower. In a passage indicative of McConnell's ire he writes,

On several occasions I have been on the point of resigning from the Wilderness Society in a cloud of smoke (and a clap of thunder); I have been utterly disgusted with the shenanigans on the recreation bill, appalled by the incompetence of the Mountaineers, the proclivities for accommodation to the bureaucracy by the Parks Assn [National Parks Association], angered by the greedy provincialism of the Mazamas, nauseated with the conservatism and lack of perspective of some elements of the Sierra Club.

Nevertheless, he understood that in order for a national park in the North Cascades to become established he and other like-minded individuals needed to convince conservationists to unite around a proposal for a national park. McConnell believed that they “just don't know yet what is at stake and are also inclined towards defeatism, particularly the Washington state people." To combat their defeatist attitude and inform them of what was really at stake, McConnell believed that the most important step was to show them the film Wilderness Alps of Stehekin. ${ }^{106}$

\section{Forest Service and Wilderness Areas: The 1950s in the North Cascades}

In 1955 Grant McConnell was one of the few people on the eastern side of the North Cascades who was even aware of a change occurring. The North Cascades were still one of the most remote places in the continental United States and were slow to feel the consequences of the post-World War II economic boom. As historian David Louter writes,

${ }^{106}$ Grant McConnell to David Brower, 28 February 1958, SCOEDR, box 6, folder 11. 
An estimated fifty-two million automobiles were on the road in the middle of the decade, many of them packing the nation's parks, but the range appeared unaffected; it epitomized the geography of wilderness. It seemed to raise an impenetrable shield to progress, turning back numerous road projects since the turn of the century, leaving the heart of the range a wild country so primitive and vast that it seemed forever new and waiting to be explored. $^{107}$

While large-scale logging was not proposed in the Stehekin area until the mid 1950s, the western valleys did not enjoy the same level of geographic isolation. In the early 1950s the Forest Service "began to reevaluate national forests, including the North Cascades, to meet the demands of the postwar housing boom and the pressures of a rising population." 108 The area under immediate threat included the west side river valleys of the Suiattle, White Chuck, and Sauk. Conservationist Robert "Bob" Marshall had attempted to preserve large sections of these valleys as wilderness in the late 1930s. Despite Marshall's advocacy and also because of his untimely death in 1939, the Forest Service never officially approved his proposal. In fact, the Forest Service ended up setting aside only 350,000 of the 794,440 acre Marshall proposal and not even as wilderness. In 1940 the Forest Service designated the 350,000 acres as the Glacier Peak Limited Area, which afforded only temporary protection to the area. ${ }^{109}$

\footnotetext{
${ }^{107}$ Louter, Contested Terrain, 27.

${ }^{108}$ Louter, Contested Terrain, 27.

109 Sommarstrom, "Wild Land," 8-39. See also Marsh, Drawing Lines, 5, 23-24, 41; The United States Forest Service partitioned its land into different management categories. These management areas placed greater restrictions on land inside its boundaries and allowed certain areas to be preserved for their scenic value. Relevant designations in the North Cascades included "primitive area," "wild area," "wilderness area," and "limited area." Marsh notes that wild and wilderness areas had stricter regulations than primitive areas because logging and road building were not allowed. However, a "limited area" was a land use category "unique to the national forests of Oregon and Washington" and it "offered significantly less protection than wilderness or primitive areas did." In fact, a "limited area" only served as a temporary designation until the Forest Service conducted appropriate land-use studies and determined an area's more permanent designation and boundary.
} 
A permanent reclassification of the Glacier Peak Limited Area to a Glacier Peak Wilderness Area became the focus of Seattle conservationists in the early 1950s. The Mountaineer Conservation Committee took the lead and was influenced greatly by a member named Dick Brooks who, according to Polly Dyer, would "harangue and harangue and harangue about Glacier Peak...if he hadn't harangued and he hadn't gotten the message across to all of us, we might not have done anything about Glacier Peak and the North Cascades. ${ }^{~} 110$ Once the notion of the importance of a Glacier Peak Wilderness Area was clear to Polly Dyer, she and the Federation of Western Outdoor Clubs let Forest Service representative Dick Bowe know at the club's convention in 1953 that the Glacier Peak Limited Area reclassification was their top priority. The Mountaineer Conservation Committee even went as far as publishing 25,000 copies of a brochure supporting a Glacier Peak Wilderness Area. ${ }^{11}$

At this point, Seattle conservationists viewed a Forest Service-managed Glacier Peak Wilderness Area as the answer to scenic resource preservation in the North Cascades. Howard Zahniser had yet to gain passage of his wilderness bill charging Congress with the oversight of the nation's wilderness areas, and all thoughts of a national park had died with the failure of the Icy Peaks proposal in the early 1940s. ${ }^{112}$ In fact, Bob Marshall had disapproved of Park Service control of the area from the beginning. He wrote to fellow conservationist Irving Clark,

\footnotetext{
${ }^{110}$ Dyer, "Preserving Washington," 31-32.

${ }^{111}$ Dyer, "Preserving Washington," 32.

112 The Icy Peaks Proposal was the last failed attempt at a national park in the North Cascades. In November 1937 a study team recommended a 5,000 square mile national park encompassing most of the Washington Cascades and all five of its volcanic peaks. The proposal was both extremely ambitious and controversial, and Secretary of the Interior Harold Ickes abandoned the Icy Peaks Proposal in August 1940. Louter, Contested Terrain, 20-25.
} 
I honestly believe that the Forest Service wilderness areas... are far safer than Park Service wilderness areas. Because of this belief, which I entertained long before I came to the Forest Service, I advocated for 6 years that the entire North Cascade country, down to Stevens Pass, should be created as a National Forest wilderness. I know and you know perfectly well that if this area should be made a park it would have roads extended into its heart. ${ }^{113}$

As the creator of the first wilderness designations in the United States, the Forest Service appeared to the majority of pre-World War II conservationists as the better choice for managing the North Cascades. The perception that the Park Service was an agency focused on developing parks for tourism continued into the postwar era. Founded on the paradoxical principle of preservation and use, the National Park Service was forced to balance these "twin mandates."

When the National Park Service was created in 1916, the Forest Service gained a bureaucratic rival for the management of public land. The United States Forest Service, founded in 1905, was put in charge of the country's forest reserves. Under the leadership of Gifford Pinchot, the Forest Service adopted a utilitarian conservation philosophy defined as "'the greatest good to the greatest number for the longest time.","114 As Pinchot stated in a speech, "The object of our forest policy is not to preserve the forests because they are beautiful... or because they are refuges for the wild creatures of the wilderness...but (because they provide) the making of prosperous homes.... Every other consideration comes as secondary." 115 As historian Lauren Danner writes, "Pinchot clearly regarded the national forests as a resource to be used, and organized the Forest

${ }^{113}$ James M. Glover, A Wilderness Original: The Life of Bob Marshall (Seattle: Mountaineers, 1986) 248.

${ }^{114}$ Paul W. Hirt, A Conspiracy of Optimism: Management of the National Forests Since World War Two (Lincoln: University of Nebraska Press, 1994), 32. Hirt quotes Pinchot from Gifford Pinchot, The Fight for Conservation (New York: Doubleday, 1910), 48-49.

${ }^{115}$ Samuel P. Hays, Conservation and the Gospel of Efficiency: The Progressive Conservation Movement, 1890-1920. (Cambridge, MA: Harvard University Press, 1959), 41-42. Hays quotes Pinchot from a March 1903 address he gave to the Society of American Foresters. 
Service accordingly. The Service was therefore established under an economic

environmental value that promoted judicious resource use."116

Competition from the Park Service forced the Forest Service to reconsider its

policy towards scenic resources. As Sommarstrom writes, in the 1920s

the Forest Service was undergoing a reexamination of its traditional utilitarian outlook; and a movement, led by men like Aldo Leopold, Robert Marshall, and Ferdinand Silcox, began to develop to preserve wilderness on national forest lands.... The establishment of these areas reflected a growing concern by the public and some of the members of the U.S. Forest Service to retain a portion of America's wildlands in pristine condition. ${ }^{117}$

In this way, the Forest Service usurped the Park Service's role as the protector of

wildness in the 1920s. The Forest Service would maintain its reputation for preserving

wilderness areas into the 1950s; however, its grip began to loosen in the years after

World War II.

Concern over the protection of the Glacier Peak and other areas of the North

Cascades arose as the 1950s rolled along. The Forest Service under the leadership of

Chief Forester Richard McArdle began to take a more active approach to managing the

nation's forests. ${ }^{118}$ As David Louter notes, this meant "cooperating with private industry, 'upping the cut' on national forests to operate the agency in the black, building logging

roads for timber access, and conducting a timber resources review to assess the future of

\footnotetext{
${ }^{116}$ Danner, "Cultural Values," 106.

117 Sommarstrom, "Wild Land," 32.

${ }^{118}$ Richard E. McArdle was a very skilled forest researcher. After having served in World War I, McArdle attended the University of Michigan and received both undergraduate and graduate degrees in forestry. He first worked for the Forest Service as a silviculturist at the Pacific Northwest Forest and Range Experiment Station in Portland, Oregon. McArdle later earned a doctorate degree and became the first chief of the Forest Service to have this distinction. McArdle was a strong proponent of multiple use and during his watch Congress passed the Multiple Use- Sustained Yield Act of 1960. See Elwood R. Maunder, Dr. Richard E. McArdle: An Interview with the Former Chief, U.S. Forest Service, 1952-1962 (Santa Cruz, CA: Forest History Society, 1975).
} 
the nation's timber supply, which, it concluded, could only be maintained through intensive management." Moreover, in the eyes of conservationists, "the Forest Service's multiple-use policy, though it implied managing forests for a balance of timber, range, water, wildlife, recreation, and other resources, seemed to favor timber harvests over wilderness preservation."119 The Forest Service had changed its policies and entered a new era of "intensive" management.

Because of the quality and accessibility of their timber, the western slopes of the North Cascades were hit the hardest. In the eyes of ardent preservationist Harvey Manning, the Forest Service actively undermined wild and scenic beauty in favor of timber interests. Consequently, nature lovers and outdoor enthusiasts alike bore the brunt of this policy shift. In a telling vignette, Manning described the process at work:

Step by step, the Barbecuers ${ }^{120}$ would advance up a valley from the mountain edge to the deep interior. They were perhaps a dozen years or more getting there, so that hikers lost a mile or two of wilderness trail a year. An intensified Forest Service would then initiate a new cutting circle by basically ramming a road the full length of the valley and locating the very first clearcut, quite purposefully, deep in the mountain interior; in a year or two they removed the entire valley from wilderness and any possibility of protected status, as happened with the middle and South Forks of the Nooksack River, for example, or the White Chuck River, or the Sauk, Stilliguamish, Skykomish Rivers, and countless others. The hikers of the 1950s found themselves driving long distances through virgin forest to a trailhead in a road-end clearcut, formerly the location of the camp at the end of a backpack of two or three days. ${ }^{121}$

\footnotetext{
${ }^{119}$ Louter, Contested Terrain, 28.

${ }^{120}$ The term Barbecuers evokes the phrase "The Great Barbecue," which Manning attributes to Bernard DeVoto. Manning states that DeVoto used the phrase to describe "the period when some forty million acres — all but seven percent_ of the State of Washington-to-be were transferred from the Original Inhabitants to the federal government and thence, for the major part, quickly into the clutch of New Arrivals." The "Barbecuers" then exploited some of this land for its natural wealth, which usually included timber and/or minerals. See Manning, Wilderness Alps, p. 35.

${ }^{121}$ Manning, Wilderness Alps, 81.
} 
The timber industry's focus on western forests and the Forest Service's switch to intensive management meant that millions of board feet once too remote for development became a valuable resource. As a result, the relatively untouched old growth forests of the west side became blemished and Seattle conservationists grew eager for a Glacier Peak Wilderness Area.

Consequently, conservation groups began to push harder for an expanded reclassification of the Glacier Peak Limited Area. In 1955 the Federation of Western Outdoor Clubs urged "the Forest Service to proceed with the study of the Glacier Peak Limited Area and asked that the 794,440-acre "Silcox Area"... be classified as wilderness." 122 The following year the Mountaineers repeated the request of the Federation, and the Forest Service finally expedited its study of the area. ${ }^{123}$ On February 7, 1957 the Forest Service released the "Glacier Peak Land Management Study," tentatively proposing a 434,310 acre Glacier Peak Wilderness Area. ${ }^{124}$ The proposal excluded the Stehekin Valley and actually decreased the amount of protected area in the western river valleys.

\section{8: The Year Conservationists Unite}

The Forest Service's disappointing proposal further justified Brower and McConnell's belief in a national park. A few months later, Ned Graves (western representative of the National Parks Association) admitted to McConnell and Ed

\footnotetext{
${ }^{122}$ Sommarstrom, "Wild Land," 44. Here Sommarstrom uses the term "Silcox Area" to refer to the area Robert Marshall and Ferdinand Silcox recommended for wilderness protection.

123 Sommarstrom, "Wild Land," 45.

${ }^{124}$ Manning, Wilderness Alps, 105.
} 
Wayburn that the Upper Stehekin Valley should be preserved as a national park. ${ }^{125}$ However, conservationists were still far from united on the issue in 1957. Although the Forest Service's preliminary proposal for a Glacier Peak Wilderness Area was disappointing, no conservationist was openly advocating for a national park at this point. ${ }^{126}$ In private the Sierra Club trio of David Brower, Grant McConnell, and David Simons were convinced of a national park solution, but it was Brower who chose the film Wilderness Alps of Stehekin as the medium through which to publicize the idea.

Because Brower, McConnell, and Simons had little connection to the Mountaineers in the early 1950s, they were not as invested in the Glacier Peak Wilderness Area proposal as certain Seattle-based activists. Although in support of their colleagues and wishing to see the Glacier Peak region given proper protection, the three men believed that the scenic climax of the North Cascades centered on the "Lake ChelanStehekin complex." ${ }^{127}$ Moreover, the recent elimination of 53,000 acres of old growth forest in the reclassification of the Three Sisters Primitive Area signaled to Brower that the Forest Service could not be trusted to preserve anything green.

After the premiere of Wilderness Alps of Stehekin, wider national park support among conservationists quickly appeared. Only two months after the film's release, the National Parks Association recommended that the Forest Service and the Park Service "enter discussions aimed at establishing a national park in the North Cascades."128 On July 4, 1958 the Sierra Club Board of Directors "voted unanimously to urge "careful

\footnotetext{
${ }^{125}$ McConnell Interview, "Conservation and Politics," 17.

${ }^{126}$ For a history of prewar national park proposals in the North Cascasdes see Louter, Contested Terrain, 10-25.

${ }^{127}$ David Brower to Patrick Goldsworthy, 13 November 1957, NCCCR, box 1, folder: David Brower $1957-$ 1959.

${ }^{128}$ Sommarstrom, "Wild Land," 48.
} 
consideration by the National Park Service of national park status for the general area." ${ }^{129}$ Support among conservationists for a national park in the North Cascades was not always unanimous. The North Cascades Conservation Council's Executive Committee supported a national park by a mere three-to-two vote. ${ }^{130}$ However, on July 26, 1958 the NCCC board more emphatically declared in a twelve-to-two vote that Congress should "direct the Secretary of the Interior to study the North Cascades from Stevens Pass to the North Cascades Primitive Area and recommend which parts of the region should be protected under the basic policy set forth in the National Park Act of 1916." ${ }^{131}$ Furthermore, the NCCC also approved "the beginnings of a study of the North Cascades by the North Cascades Conservation Council," which would ultimately lead to J. Michael McCloskey's Prospectus for A North Cascades National Park in $1963 .{ }^{132}$ The North Cascade Conservation Council (NCCC) was a conservation group based in Seattle and dedicated specifically to preserving the wild landscapes of the North Cascades. Grant McConnell first saw the value and need for creating "a single-purpose organization for that area alone.” Some conservationists, such as Patrick Goldsworthy, initially failed to see the value in creating such a council. Goldsworthy believed that the Mountaineers Conservation Committee and the Pacific Northwest Chapter of the Sierra Club were handling the situation and that another organization would be overkill. Moreover, the important Seattle-based conservationists were already actively involved in the Mountaineers and Sierra Club efforts. The Forest Service's February 1957 tentative proposal for a Glacier Peak Wilderness was the deciding factor. As Polly Dyer stated,

${ }^{129}$ Sommarstrom, "Wild Land," 48; Quoted from NCCC News 2, no. 11 (1958): 8.

${ }^{130}$ Sommarstrom, "Wild Land," 49.

${ }^{131}$ Sommarstrom, "Wild Land," 50; Quoted from NCCC News 2, no. 9 (1958): 4.

${ }^{132}$ Sommarstrom, "Wild Land," 51. 
"They excluded the forest and they excluded the area north of Cascades Pass. That was a crucial part... that led to forming the North Cascades Conservation Council." Pacific Northwest conservationists were called to Portland, and on March 23, 1957 the NCCC was formed. Philip Zalesky was chosen the Council's first president, and Patrick Goldsworthy served as first vice president. As the struggle for conservation of the North Cascades unfolded, the North Cascades Conservation Council would play a vital role in securing their preservation. ${ }^{133}$

In 1958 the NCCC was entering only its second year of operation, and the Sierra Club was still leading the charge for North Cascades preservation. David Brower had worked for two years to produce Wilderness Alps of Stehekin. Its premiere in March 1958 generated the first public support by conservationists for a national park in the North Cascades. However, the national park message of the film did not include any proposal with specific details. David Simons’s brief “The Need for Scenic Resource Conservation in the North Cascades of Washington" filled in the gaps. Simons comprehensively outlined the protection options for the North Cascades and argued strongly for national park protection of the Lake Chelan-Glacier Peak area. Released to a select number of activists on June 4, 1958, the brief stated, "The goals of protection in the Northern Cascades must be twofold, protection of wilderness core areas and of the extensive gateways to these cores." ${ }^{\prime 134}$ The Forest Service's tentative Glacier Peak Wilderness Area proposal offered protection to only one of the two main wilderness core areas and failed to protect the "gateways" that Simons and other conservationists believed were so

\footnotetext{
${ }^{133}$ Manning, Wilderness Alps, 109-110; Quotations from Dyer, "Preserving Washington," 34-35.

${ }^{134}$ David Simons, "The Need for Scenic Resource Conservation in the Northern Cascades of Washington" (Brief, San Francisco, 1958), 11.
} 
essential. He wrote that the "substantial wilderness core areas should be preserved, together with the several unspoiled gateways which lead to them. These gateways... lead into the wilderness from the surrounding lands devoted to commercial uses. The corridors, if unspoiled, can serve as the principal living space, to look at and to look from." ${ }^{135}$ Conservationists understood that development was going to occur in any preservation scenario in the North Cascades. Their goal was to include the wilderness core areas of Glacier Peak and Eldorado Peaks in a national park. ${ }^{136}$

Simons also listed logging, mining, hydroelectric dams, highways, overdevelopment, and grazing as the six main threats to the region (logging being the biggest and grazing the smallest). ${ }^{137}$ He saw the Forest Service as an organization "under almost irresistible pressures from commercial interests to eliminate land of supposed economic value." 138 In fact, the Forest Service refused to include many of the forested valleys leading into Glacier Peak because of their high timber value and did not include the area north of the Stehekin River to the North Cascade Primitive Area because of its potential valuable resources. Moreover, the Forest Service could not guarantee protection against mining, water development, or hunting. National parks, on the other hand, prohibited logging, mining, grazing, and water development. ${ }^{139}$

National park protection was not the perfect solution for wild and scenic preservation in the North Cascades because of the Park Service's reputation for development; however, it was preferable to the Forest Service alternative. Simons wrote:

\footnotetext{
135 Simons, "Scenic Resource Conservation," 6.

136 The Eldorado Peaks area encompasses the area north of the Stehekin River to Skagit River. The Forest Service did not include this area in its Glacier Peak Wilderness Area proposal.

137 Simons, "Scenic Resource Conservation," 7.

${ }^{138}$ Simons, "Scenic Resource Conservation," 12.

${ }^{139}$ Simons, "Scenic Resource Conservation," 10.
} 
Superlative national park caliber undoubtedly exits, as does the potential support for protecting the area under national park law. Enough support for adequate protection under Forest Service administration is not likely and the national forest laws are themselves inadequate.... The conclusion seems inescapable that it is time for a positive policy in the Northern Cascades, and that a national park is that positive policy. ${ }^{140}$

Simons proposed a national park encompassing 1.3 million acres, stretching from the North Cascades Primitive Area in the north to the Alpine Lakes Limited Area in the south. His proposal would protect "an unsurpassed alpine region second to none in the United States" and "the scenic gateways as well as the alplands, peaks, and glaciers.",141

By the summer of 1958 conservationists were rallying around the idea of a national park for the North Cascades. In March, Wilderness Alps of Stehekin introduced the idea. Less than three months later, the Sierra Club distributed David Simons's brief to key conservationists. The third and final key event of 1958 was the annual meeting of the Wilderness Society council. ${ }^{142}$ As Harvey Manning wrote,

The four-day conference was attended by some ninety-two representatives of the National Wildlife Federation, National Parks Association, Student Conservation Program (now association), Federation of Western Outdoor Clubs, Sierra Club, Trustees for Conservation (the new lobbying arm of the Sierra Club), North Cascades Conservation Council, Washington State Sportsman Council, Olympic Park Associates, The Mountaineers, Wenatchee Alpine Roamers, Yakima Cascadians, and others. ${ }^{143}$

The sheer number and diversity of conservation organizations represented made the conference an important event. The priority of the Wilderness Society in 1958 was passage of its proposed wilderness bill, which would have Congress establish a national wilderness preservation system. The fact that the Wilderness Society council was holding

\footnotetext{
${ }^{140}$ Simons, "Scenic Resource Conservation," 31-32.

${ }^{141}$ Simons, "Scenic Resource Conservation." 32.

142 The meeting took place August 23-26, 1958 in Stehekin, WA.

${ }^{143}$ Manning, Wilderness Alps, 114.
} 
its annual meeting in Stehekin was a great show of support for wilderness areas in the North Cascades. Grant McConnell gave a speech in which he "lit into the Forest Service for all its policies_-its treatment of the country around us... it wasn't a very tactful speech, but it got people's attention." ${ }^{144}$ Conference participants were reminded of the sublimity of the North Cascades through a showing of Wilderness Alps of Stehekin. Among the viewers were many influential members of the Wilderness Society. ${ }^{145}$ Not since its premiere in March 1958 had Wilderness Alps of Stehekin been shown to such a large group of conservationists.

The crucial moment of the conference came when David Brower and Ed Wayburn convinced Park Service director Conrad Wirth and Park Service regional director Lawrence Merriam to take an airplane tour of the North Cascades. Scared of the possibility of a land grab by the Park Service, the Forest Service had denied the Park Service access to the area. Wirth, a member of the Wilderness Society, attended the meeting for personal rather than professional reasons. Brower refused to waste the opportunity, and with McConnell as tour guide they took a flight over the region. As McConnell recalls,

I was given the chore, a pleasant one, of guiding the local bush pilot on a tour of the area, along with Connie Wirth and Merriam, giving a travelog as we went. We went up over the crest.... Connie looked off in that direction and said, "What's that up there?" pointing up toward the Pickets. I said, "Well, that's out of the area" He said, "No, no. If we were ever to have a park, we'd want that!"146

\footnotetext{
${ }^{144}$ McConnell, "Conservation and Politics," 16.

${ }^{145}$ Manning, Wilderness Alps, 114.

${ }^{146}$ McConnell, “Conservation and Politics,” 16. Neither David Simons's brief nor J. Michael McCloskey's 1963 prospectus suggested including the Pickets in a national park. The region was part of the North Cascades Primitive Area, and conservationists did not view logging or development as a threat to that area. Because they were intent on using a national park to preserve threatened landscapes, they did not include the Picket Range. Conrad Wirth showed great foresight in 1958. Although he was no longer the director of
} 
Wirth was so impressed with the area that he thought it might be time for the Interior Department to approach the Department of Agriculture about a study of the area. ${ }^{147}$ Unfortunately for national park proponents, it would take almost five years for the two departments to reach an agreement on a joint study of the North Cascades.

As Sierra Club members began to envision a national park, Seattle-based conservationists such as Polly Dyer, Pat Goldsworthy, and Philip Zalesky were still focusing on the protection of the west side river valleys and the Glacier Peak region. In a letter to Partrick Goldsworthy, David Brower wrote that "the primary danger is that there will be too much emphasis on a Glacier Peak Wilderness alone. To so concentrate emphasis seems to me to be too likely to result in our insisting that a platoon carry the battle when a whole battalion is available and can carry it better." At this time, Brower was intent on creating a united front in support of a national park:

I don't think we need to divide our camps into enthusiasts for different regions. We do need to gather together the efforts of the Stehekin enthusiasts as well as the Sauk, Suiattle, Cascade River, Thunder Creek, and Entiat enthusiasts - these are all important. It just happens that the Lake Chelan-Stehekin complex is the most dramatic, even as Yosemite Valley is the most dramatic thing we have in Yosemite National Park and the High Sierra. We would make a mistake not to capitalize on its native drama. $^{148}$

Ultimately, the film and David Simons's brief convinced many important Seattle conservationists to support a national park, and the North Cascades Conservation Council

the National Park Service in 1968, the Picket Range would become one of the major focal points of North Cascades National Park.

${ }^{147}$ Manning, Wilderness Alps, 115.

${ }^{148}$ David Brower to Patrick Goldsworthy, 13 November 1957, NCCCR, box 1, folder: David Brower 19571959. 
made it official policy in July $1958 .{ }^{149}$ However, despite the message of the film and the brief, not all conservationists were immediately swayed to support a national park. Philip Zalesky still favored Forest Service management and held out against McConnell and Brower. As Grant McConnell recalls,

In the $\mathrm{N} 3 \mathrm{C}$ there was some passionate opposition. This came from Phil Zalesky, who's a grand fellow. He was opposing it. In the open, in an N3C board meeting, and we decided we had to fight this thing through and couldn't delay it—so, in a very brutal discussion Dave and I pushed this thing through. We were going to go for a national park, and we did it over the prostrate body of Phil Zalesky. 150

Not even the most ardent pro-Forest Service conservationists could hold out against a national park much longer. In February 1959 the Forest Service released "a revised proposal for a 422,925-acre Glacier Peak Wilderness Area, a reduction of 11,075-acres from the proposal tentatively approved two years earlier. The reductions had occurred chiefly through expansion of the nonwilderness stream corridors deeper into the proposed wilderness." ${ }^{151}$ Any hope that the Forest Service would provide adequate protection for Glacier Peak seemed lost, and even Philip Zalesky "came around and became a very active supporter."152

The film Wilderness Alps of Stehekin helped to broaden the perspective of conservationists beyond the singular value of a Glacier Peak Wilderness Area through a powerful visual story and eloquent narration highlighting the beauty of Stehekin Valley. The film articulated the idea of a national park for the region including Glacier Peak, the Eldorado Peaks, Stehekin Valley, and Lake Chelan. When they considered the force of

\footnotetext{
${ }^{149}$ Dyer, "Preserving Washington," 38.

${ }^{150}$ McConnell, "Conservation and Politics,"18.

151 Sommarstrom, "Wild Land," 45.

${ }^{152}$ McConnell, “Conservation and Politics,"18.
} 
the film and David Simons's proposal for a national park, many conservationists quickly united around the idea. Ultimately, Northwest conservationist Harvey Manning was correct when he wrote, "In retrospect, it is clear that 1958 was the turning point at which the fight against the Barbecuers of the North Cascades became a burgeoning stampede for a national park." 153

${ }^{153}$ Manning, Wilderness Alps, 121. 


\section{Part 4: The Key Publicity Tool}

A week after the premiere of Wilderness Alps of Stehekin, Charlotte Mauk of the Sierra Club wrote an influential letter to members of the North Cascades Conservation Council. She began the letter by posing the question, "If one picture is worth ten thousand words, what must be the value of a thousand or two thousand feet of fine motion pictures?" The value was ultimately the support needed to convince Congress to establish a North Cascades National Park. Throughout the ten and a half years from its premiere in March 1958 to the signing of the North Cascades Act in October 1968, the film was the greatest publicity tool available to park proponents. Mauk accurately describes the persuasive value of the film in the letter's third paragraph:

We who have seen the Glacier Peak area do not need to be told how beautiful it is, or how urgently it needs protection that will preserve its wildness. But for everyone of us who appreciates wilderness and understands why it must be protected there are thousands who do notwho either do not realize how little wilderness is left, or do not know how vulnerable it is, or who do not grasp its increasing importance to civilization. Yet it is on these unknown and unknowing thousands that we must depend for support. Such a film as "Wilderness Alps of Stehekin" can help them to gain necessary understanding-if they but see the film.

The film certainly had played a crucial role in uniting conservationists in 1958 , but its real power lay in its ability to convince many people within Washington State and across America that the North Cascades were a national treasure worth saving. ${ }^{154}$

\section{The Early Years: 1958-1963}

In the late 1950s the North Cascades were one of the most remote regions left in the continental United States. Around four million acres of spectacular rugged mountains,

${ }^{154}$ Charlotte Mauk to NCCC Members, 29 March 1958, NCCCR, box 1, folder: Miscellaneous Jan-July 1958. 
glacially gouged valleys, and pristine old-growth forest from Stevens Pass to the Canadian border were largely unknown. Grant McConnell identified the area's size and remoteness as the two biggest challenges conservationists had to overcome in order to protect it. The sheer size of the region created a problem because it meant that adequate protection would have to encompass "a very substantial tract." The second problem McConnell identified was its remoteness. Because the area was largely inaccessible, few people were aware of the magnificence of the North Cascades. Consequently, people assumed falsely "that the area will not stand comparison with some of the more famous areas." McConnell then suggests, "The first necessity in any program for conservation of the area... is to call the unique values of the area to public attention." The film Wilderness Alps of Stehekin underscored "the unique values" of the North Cascades and illustrated to its viewers that the North Cascades were comparable to other national treasures such as the Grand Canyon and Yosemite and deserved protection as a national park. $^{155}$

After viewing Wilderness Alps of Stehekin in March 1960, a World Geography ninth grade class wrote reflective letters to the NCCC about the film. The letters provide substantial insight into the persuasive power of the film, its ability to resonate with young people, and its success in highlighting the spectacular beauty of the region. Student Jenny Breeden wrote, "This film showed how beautiful our wilderness really is.... Until this film I had no idea there was such a place as the Glacier Peak Wilderness. This would be a good place to spend a vacation if you like to camp out. It's really to[o] bad they don't

${ }^{155}$ Grant McConnell to William O. Douglas, 9 May 1959, SCOEDR, box 6, folder 11. 
show films on other parks to get you interested in them." ${ }^{, 156}$ Another student-Linda Hybak-wrote that she never realized "how much unspoiled land we had or how wonderful it was. There are so many beautiful flowers, grasses, trees, mountains, hills, and glaciers. I want to get out and see all these things and I'm sure many others do too.... I think it is up to us to keep this natural beauty safe...."157 Sharon Briggs closely supported McConnell's belief in the national grandeur of the North Cascades. She wrote, "I enjoyed the film immensely. The scenery was beautiful, in fact I've traveled all over this United States and seen some beautiful scenery, but this was some of the most beautiful I've ever seen." ${ }^{158}$ On the same point Bob Pike wrote, "Never before have I seen anything so inviting.... I have seen the Grand Canyon myself.... The Glacier Peak Wilderness and all the other places around this wonderful place have a world for its own [sic]." ${ }^{159}$ Wilderness Alps of Stehekin helped Washington's young and old recognize the existence of a national treasure in their own backyard.

As Figure 4 shows, Wilderness Alps of Stehekin was popular not only in Washington State but across the nation. As David Brower wrote in July 1958, "The movie is on the road, and thanks to the good efforts of a lot of people who are showing it all over the country, is making the national-park potential more widely known." 160 The

\footnotetext{
156 Jenny Breeden, “The Stehekin Alps," March 1960, NCCCR, box 1, folder: Incoming Letters re: "The Stehekin Alps" film - from students 1960.

${ }^{157}$ Linda Hybak, "Stehekin Alps," 31 March 1960, NCCCR, box 1, folder: Incoming Letters re: "The Stehekin Alps" film - from students 1960.

${ }^{158}$ Sharon Briggs, "Film," 31 March 1960, NCCCR, box 1, folder: Incoming Letters re: "The Stehekin Alps" film - from students 1960.

${ }^{159}$ Bob Pike, "Stehekin Alps," 31 March 1960, NCCCR, box 1, folder: Incoming Letters re: "The Stehekin Alps" film - from students 1960.

${ }^{160}$ David Brower to Grant McConnell, 11 July 1958, NCCCR, box 1, folder: David Brower 1957-1959.
} 
first showing of the Appalachian Mountain Club's copy occurred at an inter-chapter meeting on May 24, 1958, and "it met with the unanimous approval of all who saw it."161

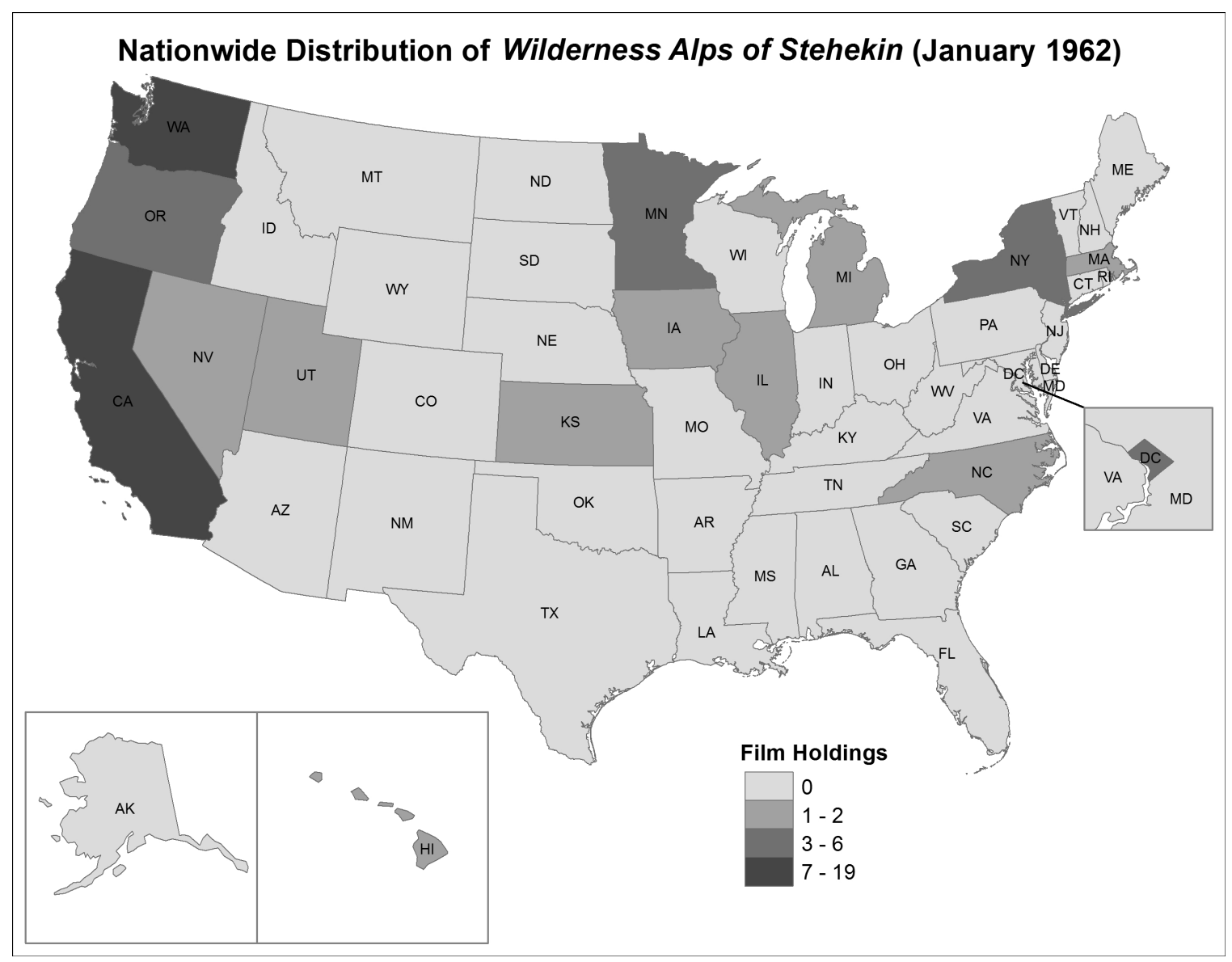

Figure 4. Nationwide Distribution of Wilderness Alps of Stehekin (January 1962). ${ }^{162}$

Moreover, in its first year of circulation, the Angeles Chapter of the Sierra Club recorded twenty-nine bookings. Some of the requests were for multiple showings and "one booking was for showing at six different locations." T.D. Atkinson of the Angeles Chapter estimated that during its first year in southern California Wilderness Alps of

\footnotetext{
${ }^{161}$ Fran Belcher to David Brower, 3 June 1958, SCOEDR, carton 23, folder 33.

${ }^{162}$ Henry Underwood, "Nationwide Distribution of Wilderness Alps of Stehekin (January 1962)," Map, 2013.
} 
Stehekin was shown more than forty times. Atkinson also reported an unforeseen positive effect of the film: the Sierra Club in his area was seeing a spike in membership applications, and "among the reasons mentioned for being interested in the Sierra Club has been the Stehekin film."

Demand for Wilderness Alps of Stehekin was so high in Washington State by December 1958 that Patrick Goldsworthy was compelled to write to David Brower requesting additional copies. According to Goldsworthy, Northwest conservationists were "being swamped for showings and can't handle all of them with the four copies we have here in Washington." 164 Goldsworthy claimed in early February 1959 that individuals in Washington had shown Wilderness Alps of Stehekin and Chuck Hessey's film Glacier Peak Holiday "to well over 10,000 people so far... We are constantly told what excellent movies these are and have been asked again and again to show them." ${ }^{165}$ The degree of success that Wilderness Alps of Stehekin achieved in its eighteen months surprised conservationists everywhere, including its producer David Brower, who wrote to Abigail Avery in June 1959, "It seems to have achieved far more than I ever imagined it could." 166

The mode in which the film was distributed and shown to audiences is somewhat foreign to contemporary sensibilities. Despite many viewers, it was never shown in a movie theater or to a national television audience. Instead, individuals or groups held public and private showings of the film upon request and borrowed it from one of the

\footnotetext{
${ }^{163}$ T.D. Atkinson to David Brower, 28 April 1959, SCOEDR, carton 23, folder 33.

${ }^{164}$ Patrick Goldsworthy to David Brower, 22 December 1958, NCCCR, box 1, folder: David Brower 19571959.

${ }^{165}$ Patrick Goldsworthy to Earl Hartley, 9 February 1959, NCCCR, box 2, folder: Miscellaneous Jan -Apr. 1959.

${ }^{166}$ David Brower to Abigail Avery, 4 June 1959, SCOEDR, carton 23, folder 33.
} 
organizations that owned a copy. The Sierra Club made 125 copies available for purchase, but the number of copies in circulation at a given time was always smaller. As Figure 4 illustrates, sixty copies were located in fifteen different states and the District of Columbia in January 1962. This map shows that the film was viewed not only on the West Coast, but also in key location in the East and Midwest. Conservation organizations owned the majority of films, but different government agencies, churches, and libraries around the country also held a fair number of copies. ${ }^{167}$

These organizations would lend the movie either for free or for a nominal fee to an individual or group who would show it to an audience ranging from a few to several hundred people. Audiences commonly included church groups, women's clubs, high school classes, college students, Boy Scout troops, conservation groups, and garden clubs. Because the film was so well done, it was very popular and demand for it was consistently high. When the film was made available for purchase in the spring of 1958 , it cost a substantial $\$ 156$ per copy. Since many organizations could not afford that, David Brower and the Sierra Club sent copies to conservation organizations such as the North Cascades Conservation Council, Appalachian Mountain Club, and Izaak Walton League at no initial cost. Once the organization had raised enough revenue through lending of the film, the organization would pay the Sierra Club. ${ }^{168}$

Since Wilderness Alps of Stehekin was produced on $16 \mathrm{~mm}$ film, it had to be shown using a compatible projector. Because projectors were much less ubiquitous than the modern DVD players, showings of the film could occur only in places where a

\footnotetext{
${ }^{167}$ January 1962 Holdings of Wilderness Alps of Stehekin, SCOEDR, Carton 78.

${ }^{168}$ David Simons to Abigail Avery, 8 April 1958, SCOEDR, carton 12, folder 14; David Brower to Frank Gregg, 10 June 1958, SCOEDR, carton 23, folder 33.
} 
projector existed or was brought in. Consequently, a higher degree of logistical planning was necessary to show Wilderness Alps of Stehekin, and occasionally the lending organization would need to send along a projector to accompany the film. According to Patrick Goldsworthy, the North Cascades Conservation Council would mail the film "all over the state" and even send it by bus: "We found that the post office wasn't too reliable, and it was better to put it on a Greyhound bus, then you knew exactly when it would get to its destination." ${ }^{, 69}$ Film distribution in the 1950s and 1960s certainly took more time and more planning than it would today. Nonetheless, despite the logistical difficulties, the film reached a large audience and proved extremely influential.

As the film shaped public perception and mobilized support for a North Cascades National Park, the Washington State delegation and Congress was feeling increased pressure to take action. In many ways, the decision for a national park fell to Senator Henry M. Jackson, who was the key politician in Washington State. As the chairman of the Senate Committee on Interior and Insular Affairs, Jackson had the power to move legislation establishing a North Cascades National Park through the Senate. As Michael McCloskey recalls, "No member of Congress from anywhere in the country would cross him on this issue or try to beat their head up against the wall if he was not willing to move, so he was absolutely indispensible. He had to move in our direction and embrace us or we were dead in the water." Because of Jackson's "towering national importance," a successful campaign for a North Cascades National Park centered more on building up a favorable statewide constituency than did other similar conservation campaigns of the

${ }^{169}$ Patrick D. Goldsworthy, "Protecting the North Cascades, 1954-1983," 78. 
time. ${ }^{170}$ As a result, McCloskey viewed the film primarily as a useful tool for convincing the Washington State constituency and congressional delegation that a national park was in their best interest: "The film and books in the late 50s and early 60s had a very valuable function vis-à-vis Jackson.... And once they got him aboard... [they needed] to convince him to get behind a park solution and protecting more nature."171

Senator Jackson wished for Washington State conservationists to lead the charge for a national park, because it would be "much more difficult for him to support a conservation cause in the northwest if the added complication of non-Washingtonians appearing to be leading the cause exists." ${ }^{172}$ In other words, the Sierra Club, which had produced the film and brief in 1958 and had started the movement towards the national park, would need to take a back seat to the North Cascades Conservation Council if a national park was ever to become a reality. After 1958, the NCCC did take the lead on the North Cascades within the state of Washington. The Sierra Club remained the point conservation organization for the North Cascades on the national level; however, increasingly the struggle for a national park in the North Cascades would hinge on the Washington State delegation. Although Brower, McConnell, and Simons were all important members of the NCCC, President Patrick Goldsworthy emerged during the 1960s as the leading figure in North Cascades conservation. Having set the agenda

\footnotetext{
${ }^{170} \mathrm{~J}$. Michael McCloskey, interview by author. In the interview McCloskey contrasted the Redwoods National Park campaign with the North Cascades National Park campaign.

${ }^{171}$ J. Michael McCloskey, interview by author. In June 1965 David Brower and the Sierra Club released an Exhibit Format book on the North Cascades. The Wild Cascades: Forgotten Parkland by Harvey Manning showcased the beauty of the region through large photographs and accompanying text. Published over seven years after the premiere of Wilderness Alps of Stehekin, the book's greatest utility was in publicizing the North Cascades and their need for national park protection to Congress. In fact, Brower sent a copy of the book to every member of the Senate and House. ${ }^{171}$ The book included a sixteen-page section called "Wilderness Alps," featuring photographs and text adapted from Brower's film narration.

${ }^{172}$ Patrick Goldsworthy to David Brower, 22 December 1958, NCCCR, box 1, folder: David Brower 19571959 (Goldsworthy wrote two letters to David Brower on 22 December 1958).
} 
towards a national park, the Sierra Club would assume a supporting role from this point forward. $^{173}$

Wilderness Alps of Stehekin screenings often included more than just thirty-one minutes of footage. After the film was shown, a supporter would often give a talk on the North Cascades and hand out brochures in order to inform the audience of the ways in which it could help. Brochures such as "Our Greatest National Park?” and "The Last Chance for a Northern Cascades National Park" gave the viewers something tangible to hold on to after viewing the film and provided instructions on what an individual could do to help. The brochure “Our Greatest National Park?" listed three points under the heading "What You Can Do." The first point encouraged people to visit the area and see the landscape for themselves. The second point in bold font stated "ask the President, your Congressman, your Senators and other friends of conservation to insist that this region be protected with the best skill and law our government has evolved. Your letters count!" The third and final point instructed those who had already viewed Wilderness Alps of Stehekin to host a showing of the film. ${ }^{174}$ Although the brochures were not designed solely as post-film literature, they proved an effective complement to the film. Conservationists did not want people to see the film, be impressed, and then ultimately do nothing. They hoped the brochures would encourage letter writing, additional film

\footnotetext{
${ }^{173}$ See Harvey Manning, "You Don't Have to be Old to be an Elder: Elder of the Tribe: Dave Simons (1936-1960)," Backpacker, Spring 1975, 56-59, 84-89. David Simons's supporting role would end on December 21, 1960, when he tragically died at the age of twenty-four from hepatitis at Fort Bragg, North Carolina. Simons was drafted into the army after he neglected his studies at the University of California. Instead of keeping up with his coursework, Simons devoted most his time and energy to conservation issues in the North Cascades and Oregon Cascades. His death was a major blow to scenic preservation, especially in the Pacific Northwest.

${ }^{174}$ Our Greatest National Park? (San Francisco: Sierra Club, 1959).
} 
screenings, and enhance the effect of the film on swaying public opinion in favor of a national park.

Screenings of the film encouraged letter-writing and additional screenings, thus enhancing the support of Washington's congressional delegation. A good example is a response written to the film by ninth grader Carolyn Jonson: "The Stehekin Alps was a very good movie and it convinced me to talk to my parents and to have them write to Senator Jackson." ${ }^{\prime 175}$ Northwest activists also took a more direct approach to influencing their congressmen. Patrick Goldsworthy showed the film to Congressman Don Magnuson in early summer 1958. Magnuson's reaction to the film was quite positive and encouraged Goldsworthy to contact Congressman Thomas Pelly about a personal viewing of the film. Thus, the film influenced Washington congressmen directly by their viewing it and indirectly through letters they received from constituents who had seen the film and felt compelled to write. ${ }^{176}$

As conservationists united around the idea of a North Cascades national park and the movement gained popularity and strength in 1958 and 1959, the Department of Agriculture became legitimately concerned about the possibility of losing land in the North Cascades to the Department of the Interior. Shortly after the Forest Service's revised Glacier Peak Wilderness Area Proposal, Congressman Thomas Pelly—acting on behalf of conservationists - asked the National Park Service to undertake a study of the area. Conrad Wirth and the National Park Service requested permission from the Forest

\footnotetext{
175 Carolyn Jonson, "Stehekin Alps," 31 March 1960, NCCCR, box 1, folder: Incoming Letters re: "The Stehekin Alps" film - from students 1960.

${ }^{176}$ Patrick Goldsworthy to Thomas Pelly, 12 July 1958, NCCCR, box 1, folder: Miscellaneous Jan-July 1958; Patrick Goldsworthy to Don Magnuson, 12 July 1958, NCCCR, box 1, folder: Miscellaneous JanJuly 1958. Representative Don Magnuson and Senator Warren Magnuson are different people.
} 
Service to proceed, but the Forest Service denied the request. Frustrated by the stubbornness of the Forest Service, Pelly introduced bills in the House of Representatives in 1960 and 1961 proposing a Park Service study of the North Cascades. ${ }^{177}$ Although Pelly's request and bills were not acted upon directly, the outcry over the Glacier Peak proposal of February 1959 and the clamoring for a national park persuaded "the Secretary of Agriculture to overrule local Forest Service officials by adding 35,175 acres to the proposal when he established a 458,100-acre Glacier Peak Wilderness Area on September 6, 1960." ${ }^{178}$ The final Glacier Peak Wilderness Area "gained protection of the Agnes, Suiattle, and Chiwawa valleys" but was still a "pitiably small size." ${ }^{179}$ Moreover, administrative authority of the Glacier Peak Wilderness Area still rested with the Secretary of Agriculture, and a change in the size of the Glacier Peak Wilderness could be made without congressional approval. ${ }^{180}$

In 1958 the Federation of Western Outdoor Clubs first recommended "a joint study by the Interior and Agriculture Departments to determine how the area's wilderness, scenic, wildlife and recreation resources might best be protected by law." However, it would take almost five years before an agreement between the two government departments could be reached. During this time, Wilderness Alps of Stehekin

\footnotetext{
${ }^{177}$ Sommarstrom, "Wild Land," 54-56; Louter, Contested Terrain, 35-36.

${ }^{178}$ Sommarstrom, "Wild Land," 46. Conservationists were outraged at the small size of the Forest Service's 1959 Glacier Peak Wilderness Area Proposal. See David Brower, "Crisis in the North Cascades: The Missing Million," Sierra Club Bulletin, February 1959.

${ }^{179}$ Manning, Wilderness Alps, 121

${ }^{180}$ This would change with the passage of the Wilderness Act of 1964 in which the Glacier Peak Wilderness Area was made part of the National Wilderness Preservation System.

${ }^{181}$ The North Cascades Study Team, The North Cascades: A Report to the Secretary of the Interior and the Secretary of Agriculture, (Washington, DC: U.S. Department of the Interior and U.S. Department of Agriculture, 1965) 185.
} 
was used as a political tool to put pressure on the Department of Agriculture and the Department of the Interior to approve a study. As David Brower wrote,

We still need more showings, with literature to give away at the showings, telling people what to do to help, and especially in Washington. The Washington delegation, more than any other, needs to hear as soon as possible from a lot of Washingtonians letting them know that there is state-wide support. This will encourage them to see the feasibility of introducing and pushing through the park-study legislation. ${ }^{182}$

In 1961 the North Cascades Conservation Council presented Congressman Thomas Pelly with "a petition containing nearly 22,000 signatures from almost every state in the union in favor of a park study." ${ }^{183}$ The fact that the petition represented almost all fifty states spoke to the success of the film and other publicity tools in creating national awareness of the North Cascades. Even as the country grew impatient for the Forest Service and Park Service to come to an agreement over a study proposal, the Forest Service continued to award logging contracts in unprotected areas of the North Cascades. Consequently, under pressure from conservationists, Washington Senators Warren Magnuson and Henry Jackson encouraged the development of "a forest management plan for the area north of the Glacier Peak Wilderness."184 Secretary of Agriculture Orville Freeman responded to the pressure by issuing "a moratorium on logging in the region on June 7, 1961 until the Forest Service had conducted a long-range management plan." The moratorium lasted only until March 1962, when the Forest Service issued its plan. As expected, the plan was disappointing to conservationists, and Congressman Thomas Pelly urged the secretary to reinstitute the moratorium. Secretary

\footnotetext{
${ }^{182}$ David Brower to Patrick Goldsworthy, 13 November 1958, NCCCR, box 1, folder: David Brower 19571959.

${ }^{183}$ Louter, Contested Terrain, 36.

${ }^{184}$ Louter, Contested Terrain, 36.
} 
Freeman declined, and logging in controversial areas recommenced. ${ }^{185}$ As David Louter points out, "In the early 1960s, the Forest Service's resistance to the park study ran counter to the urgency expressed by increasing numbers of Americans demanding the preservation of more wild lands." 186 The images presented in Wilderness Alps of Stehekin, not the "multiple-use" attitude of the Forest Service, resonated with these Americans.

On January 28, 1963 Secretary Freeman and Interior Secretary Stewart Udall finally announced in a letter to President John F. Kennedy that the two departments had reached an agreement "on a broad range of issues," including a joint study of the North Cascades:

A joint study should be made of Federal lands in the North Cascade Mountains of Washington to determine the management and administration of those lands that will best serve the public interest. These lands for the most part have been under the administration of the Forest Service as national forests for many years. A study team will consist of representatives of the two Departments and will be chaired by an individual jointly selected by us. ${ }^{187}$

On March 5, 1963 Edward Crafts of the Bureau of Outdoor Recreation was appointed chair of the study team. The other four members were Henry Caulfield and George Hartzog from the Department of the Interior and George Selke and Arthur Greeley from the Department of Agriculture. ${ }^{188}$

During the four and a half years it took the Forest Service and the Park Service to overcome their bureaucratic rivalry, popular support for a national park in the North Cascades continued to grow. Records of Wilderness Alps of Stehekin showings are

\footnotetext{
${ }^{185}$ Louter, Contested Terrain, 36-37.

${ }^{186}$ Louter, Contested Terrain, 37.

${ }^{187}$ North Cascades, Report, 154.

${ }^{188}$ North Cascades, Report, 10. Owen Stratton replaced Henry Caulfield in September 1963.
} 
largely incomplete, but enough data exist from this period to provide a sense of the film's importance. According to information obtained from a handwritten log, the Federation of Western Outdoor Clubs' second copy of Wilderness Alps of Stehekin was shown 78 times to 5,511 people between January 1, 1959 and December 31, $1963 .{ }^{189}$ This was just one of one hundred twenty-five film copies the Sierra Club produced.

Another glimpse at the popularity of the film survives in an undated letter from Sierra Club film librarian Mrs. Robert Gauger to David Brower. According to Mrs. Gauger, in 1960 Wilderness Alps of Stehekin was shown 87 times to an estimated audience of 7,010 people. ${ }^{190}$ She also circulated the Sierra Club Bay Chapter's copy of Wilderness Alps of Stehekin, which was shown 43 times to an approximate audience of 1,853 people. ${ }^{191}$ The exact number of showings and audience size during 1960 and for the period 1959-1963 is unclear. It would be unfair and unwise to extrapolate the data available. However, it is certain that around 9,000 people saw Wilderness Alps of Stehekin through the copies distributed by Mrs. Gauger during 1960 and that around 5,500 people saw the Federation's second copy from 1959-1963. When this information is combined with the January 1962 Wilderness Alps of Stehekin distribution list verifying the location of 60 copies across the country, it is evident that a substantial number of people saw the film. ${ }^{192}$

Wilderness Alps of Stehekin reached a wide audience through private and public showings held by individuals and groups. The film also occasionally reached local

189 "Wilderness Alps of Stehekin" - Federation of Western Outdoor Clubs' Copy \#2, NCCCR, box 6, folder: Conservation Film Center 1964-1966, 1968.

${ }^{190}$ The number of copies these statistics represent is unclear.

${ }^{191}$ Mrs. Robert Gauger to David Brower, Undated, SCOEDR, carton 23, folder 18.

192 The greatest number of film copies was located in California and Washington. Every copy of the film was viewed by a different number of people, and the numerical evidence paints only a small picture of how many people saw the film. 
television audiences, although the historical record is incomplete. Shortly after holding its first showing of the film, Appalachian Mountain Club Executive Director Fran Belcher informed David Brower that it was viewed "by officials of our local educational TV station, WGBH-TV Channel 2 and has been programmed for a showing over their network. ${ }^{" 193}$ The film also made television appearances in Seattle. According to Patrick Goldsworthy, an opportunity to present an abridged version of it on one of Seattle's "strongest TV channels as 1 of a series of 13 programs of an outdoor and adventure series" presented itself in the fall of $1961 .{ }^{194}$ Moreover, evidence suggests that the film had aired three times on two different Seattle television stations by the end of August 1958, and six years later Goldsworthy and the North Cascades Conservation Council ordered two new copies of the film to "be used for a TV program that is imminent."195 These copies were shown three times on television during 1967-1968. ${ }^{196}$

After nearly five years of lobbying by various groups, a North Cascades Study Team was finally established in March 1963. The area of study to be covered was far larger than the primary region that concerned conservationists. As Lauren Danner writes, "The study area was enormous, covering a region about the size of Vermont. It included all federally administered lands in the Cascade Range north of what is now State Route 12 to the Canadian border-about seven million acres, or nearly one-sixth of the total area of the state. ${ }^{, 197}$ In order to hear the voice of Washingtonians, the North Cascades

\footnotetext{
${ }^{193}$ Fran Belcher to David Brower, 3 June 1958, SCOEDR, carton 23, folder 33.

${ }^{194}$ Patrick Goldsworthy to David Brower, 15 September 1961, NCCCR, box 1, folder: David Brower 1961.

${ }^{195}$ NCCC News, July 1958, 2. Patrick Goldsworthy to Lee Schulman, 26 June 1958, NCCCR, box 1, folder: Miscellaneous Jan-July 1958; Patrick Goldsworthy to David Brower, 22 June 1964, NCCCR, box 1, folder: David Brower 1963-1964.

${ }^{196}$ Conservation Film Center: Operations Report, 1 September 1967 to 1 September 1968, NCCCR, box 6, folder: Conservation Film Center 1964-1966, 1968.

${ }^{197}$ Danner, "Cultural Values," 152.
} 
Study Team held public hearings in Seattle on October 10 and 11, 1963. Conservationists used the opportunity to make public their Prospectus for a North Cascades National Park. ${ }^{198}$

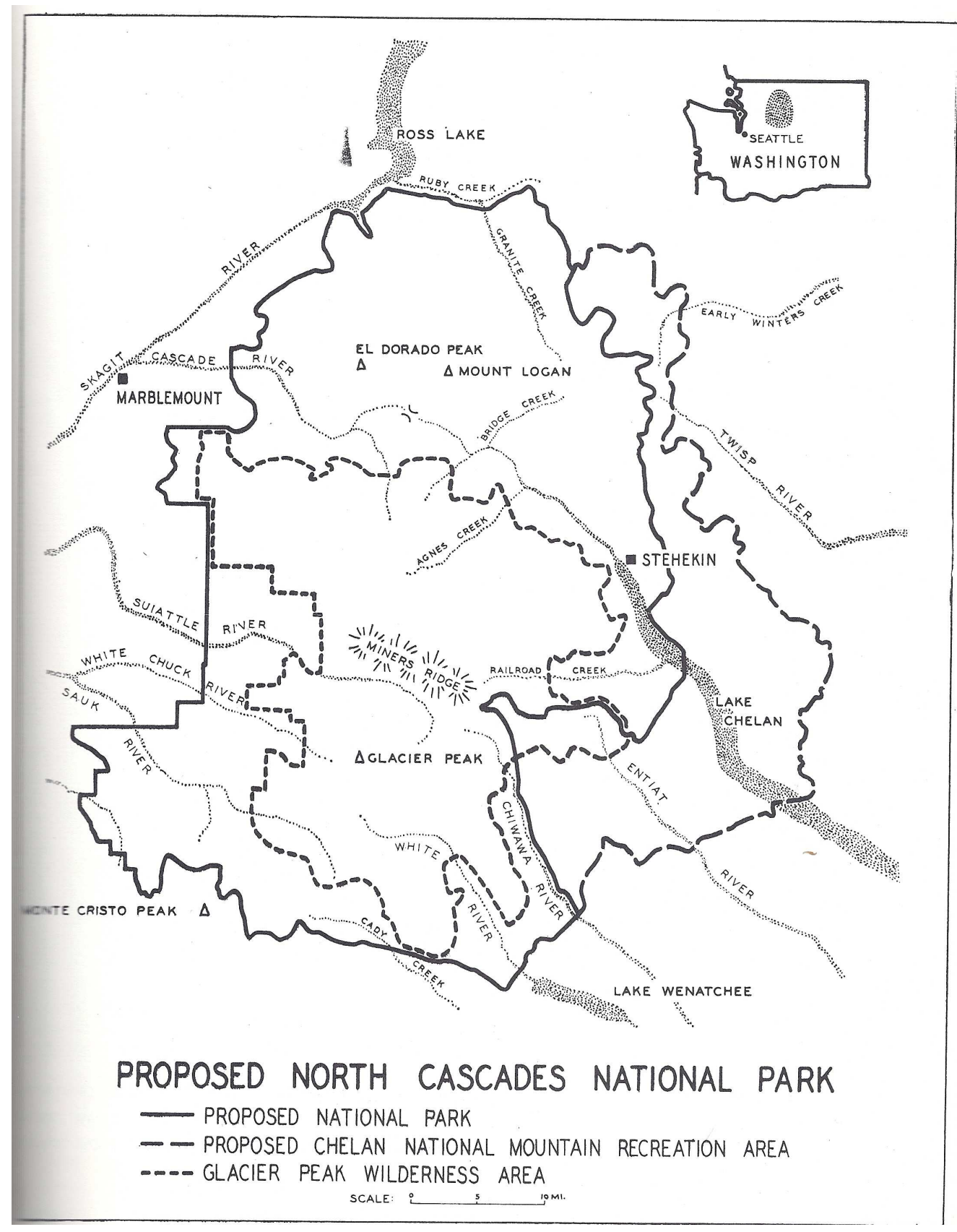

Figure 5. Proposed North Cascades National Park. ${ }^{199}$

\footnotetext{
${ }^{198}$ Danner, "Cultural Values," 153-154.

${ }^{199}$ McCloskey, Prospectus.
} 
Edited by conservationist J. Michael McCloskey, the document laid out the NCCC's proposal for a national park. McCloskey's proposal called for "a North Cascades National Park of 1,038,665 acres and a Chelan National Mountain Recreation Area of 269,521 acres contiguous with the eastern boundary of the park." 200

Ostensibly, the McCloskey 1963 Prospectus was a reincarnation of David Simons's 1958 brief. Both documents recommended a very similar area and means of protection. However, in reality McCloskey's document served a much different purpose from Simons's, and the two actually should be viewed independently. Simons's brief was directed at conservationists and in tandem with the film played a crucial role in helping to unite them initially around the idea of a North Cascades national park. McCloskey's Prospectus came at a time when they were already united and the park controversy had moved into the political arena. The Prospectus aimed at persuading politicians and the study team of the need for a national park and recreation area encompassing Glacier Peak, Eldorado Peaks, the Stehekin Valley, and Lake Chelan. Unlike Simons's brief, the document provided specific legislation and an economic analysis of the effects of a national park. ${ }^{201}$ Two years in the making, the document clearly outlined the conservationists' demands and offered a cogent argument to politicians and the study team on the need for a North Cascades National Park. ${ }^{202}$

\footnotetext{
${ }^{200}$ J. Michael McCloskey, ed. Prospectus for a North Cascades National Park (Seattle: North Cascades Conservation Council, 1963), S-4.

${ }^{201}$ See McCloskey, Prospectus, Parts IV and V.

${ }^{202}$ For a more complete analysis of the Prospectus see Sommarstrom, "Wild Land," 57-67.
} 


\section{The Home Stretch: 1964-1968}

The study team took nearly three years to survey the area, make recommendations, and write a report which was submitted in October 1965 and released to the public in January 1966. It recommended several changes in the North Cascades, including the establishment of a 698,000 acre North Cascades National Park

extending from Riddle Creek, a few miles below the head of Lake Chelan; northwestward generally along the Stehekin River to Cascades Pass and Cascade River drainage, including the Eldorado Peaks area, Thunder Creek and Granite Creek, including Ross and Diablo Lakes; crossing the Skagit River and including that part of the North Cascade Primitive Area west of Ross Lake, and Mount Shuksan.

The report also recommended reclassifying the remaining North Cascades Primitive Area as the Okanogan Wilderness Area and expanding the Glacier Peak Wilderness Boundary in three places. $^{203}$

Although the report proposed a national park far smaller than conservationists wanted and included far too much development, it gave them something to work with. As Mike McCloskey recalled, "When the Study Report came out, my first reaction was to express a great sense of grievance because it was so small. I was going to denounce it." However, David Brower convinced him to remember the words of Oregon Senator Richard Neuberger and "get on a train that's going somewhere. We can always try to get it to go further later on.... Let's start moving in the right direction." ${ }^{, 204}$ Although conservationists were savvy in not denouncing the study team's report, they did question the wisdom "of including hydroelectric projects in national parks and the uniformly bad innovations of tramways and helicopters, as well as traditional roads, to open up the

\footnotetext{
${ }^{203}$ North Cascades, Report, 14-15. For an in depth analysis of the Report see Sommarstrom, "Wild Land," 68-95.

${ }^{204}$ McCloskey, interview by author.
} 
park's high country." ${ }^{205}$ In the event, North Cascades National Park would not suffer from the effects of tramway or helicopter access.

With the release of the North Cascades Study Report in January 1966, the national park campaign entered its final phase. Before introducing legislation, Senator Jackson wanted to confirm public support for the study team's recommendation. He organized Senate Interior Committee hearings in Seattle on February 11 and 12, 1966. The hearings were very well attended and, according to Lauren Danner, the "committee members got an earful." The Committee listened to testimony from over 250 individuals and received almost 1750 letters. The public response was strongly positive with more than 63 percent favoring a national park solution, and it prompted the drafting of Senate Bill 1321, introduced by Washington senators Henry Jackson and Warren Magnuson on March 20, $1967 .^{206}$

Since its premiere in 1958, Wilderness Alps of Stehekin had played a key role in showcasing the North Cascades and gathering support for a national park. The film was especially important in convincing the Washington State constituency and Senator Henry Jackson. ${ }^{207}$ However, despite the film's central significance, the North Cascades Conservation Council's distribution of it remained loosely organized until the establishment of the Conservation Film Center in April 1964. This center was the brainchild of Louis R. Huber. As a member of the film business and the NCCC, Huber had the combination of skills and desire necessary to "handle the inspection, repair and

\footnotetext{
${ }^{205}$ Louter, Contested Terrain, 43.

${ }^{206}$ Danner, "Cultural Values," 165.

207 This thesis simplifies the political dynamics involving Senator Jackson and the rest of the Washington State delegation. There are many political factors involved with the passage of the North Cascades Act of 1968 that are not directly related to the film and therefore are not mentioned in this account.
} 
mailing of films.” Margaret Tjaden was recruited as co-director and oversaw "the booking, correspondence and contact work." The Conservation Film Center helped to organize and increase film distribution. As Louis Huber stated, "Films don't circulate themselves; they have to be circulated. Demand must be created.",208

The center had nine copies of Wilderness Alps of Stehekin by the end of 1964. These copies were pooled from Seattle-based conservation organizations and had largely been in circulation since 1958. The center's records provide the most complete picture of the film's viewership during the final years of the controversy. According to a 1968 operations report, from April 1964 to September 1968 the nine copies were shown 498 times to 29,617 people. Specifically, from September 1967 to September 1968 the film was shown 181 times to 10,000 viewers. ${ }^{209}$ Even ten years after its premiere, Wilderness Alps of Stehekin played a major role in influencing public opinion about the North Cascades.

The final chapters of the North Cascades story played out at the discretion of Congress. In April 1967 hearings were held in Washington D.C., followed by field hearings in Washington State in May. Public opinion and comments influenced the final version of the bill, and in late 1967 the Senate passed an amended version. All eyes focused on the House of Representatives in 1968 as the bill came into its hands. After a delay, Senator Henry Jackson and Colorado Representative Wayne Aspinall—chairman of the House Interior Committee—reached a political agreement, and Aspinall sent the bill out of committee for a floor vote. Both chambers of Congress passed a final version

\footnotetext{
${ }^{208}$ Conservation Film Center: Report on First Year of Operation, 27 March 1965, NCCCR, box 6, folder: Conservation Film Center 1964-1966, 1968.

${ }^{209}$ Conservation Film Center: Operations Report, 1 September 1967 to 1 September 1968, NCCCR, box 6, folder: Conservation Film Center 1964-1966, 1968.
} 
of the bill in September 1968, and on October 2, 1968 President Lyndon B. Johnson signed the North Cascades Act into law. ${ }^{210}$

Wilderness Alps of Stehekin influenced public opinion regarding the North Cascades for over ten years. From its premiere in March 1958 to the passage of the North Cascades Act in September 1968, many Americans all across the country gained their first glimpses of the spectacular mountain landscapes and forested river valleys by watching the film. Because the North Cascades were so remote and largely unknown in the late $1950 \mathrm{~s}$, the medium of film provided the perfect opportunity to showcase the region's grandeur. At the urging of the McConnells, David Brower seized this opportunity and created the single most influential publicity tool of the North Cascades campaign. As Harvey Manning so appropriately wrote, "For the nation, Wilderness Alps of Stehekin helped magnificently to win a wildland."211

\footnotetext{
${ }^{210}$ Danner, "Cultural Values," 177-182.

${ }^{211}$ Manning, Wilderness Alps, 108.
} 


\section{Conclusion}

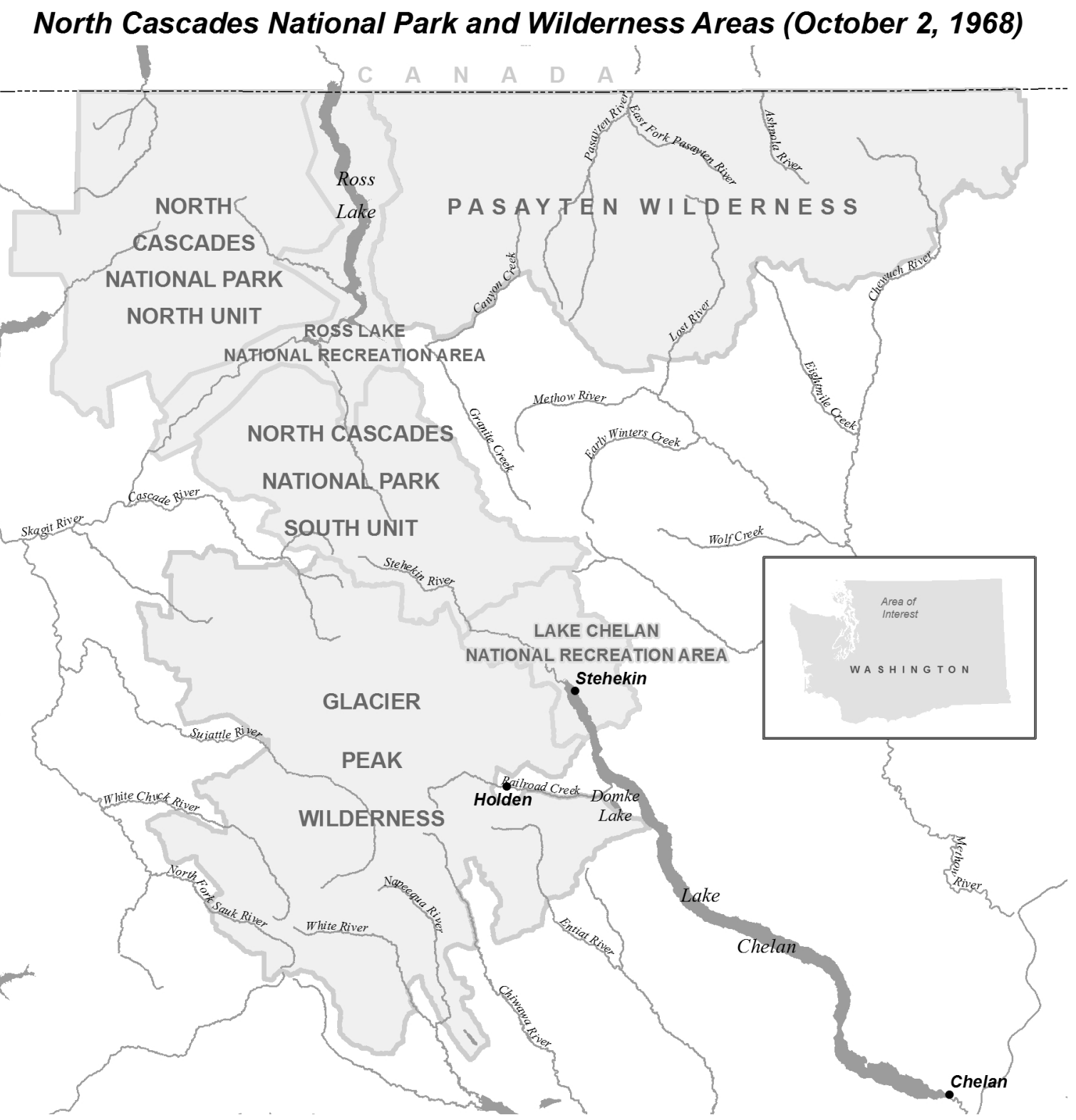

Figure 6: North Cascades National Park and Wilderness Areas (October 2, 1968). ${ }^{212}$

\footnotetext{
${ }^{212}$ Henry Underwood, "North Cascades National Park and Wilderness Areas (October 2, 1968)," Map,
} 2013. 
The North Cascades Act transferred almost 700,000 acres of land from the Forest Service to the Park Service, including a 505,000-acre North Cascades National Park, a 107,000-acre Ross Lake National Recreation Area, and a 62,000-acre Lake Chelan National Recreation Area. The Forest Service remained in charge of the newly created 520,000-acre Pasayten Wilderness Area and the Glacier Peak Wilderness Area, which received an additional 10,000 acres from the North Cascades Act. Although many conservationists were disappointed that the Glacier Peak Wilderness Area was left out of the national park, they rejoiced at the added protection national park status gave the Eldorado Peaks, Stehekin Valley, and Lake Chelan areas. ${ }^{213}$

The importance of Wilderness Alps of Stehekin cannot be overstated. Artistically and politically, it was the pinnacle of David Brower's filmmaking career, even garnering an "Honorable Mention" from the Photographic Society of America Motion Picture Division in its "Ten Best Film" category at the 1960 International Cinema Competition. ${ }^{214}$ Although Brower would play a part in several Sierra Club films produced in the 1960s such as Island in Time, Glen Canyon, and The Grand Canyon: Living River, Living Canyon, his role in all these films paled in comparison to that of Wilderness Alps of Stehekin. ${ }^{215}$ Because of a combination of human error and sickness, Brower became the primary photographer, editor, writer, and narrator for Wilderness Alps of Stehekin. His

\footnotetext{
${ }^{213}$ The Wilderness Act of 1964 placed Congress in charge of the country's wilderness areas. Under the act, Congress added the Glacier Peak Wilderness Area to the National Wilderness Preservation System. However, the act allowed for existing mining claims to be developed in wilderness areas until 1984. Because the act did not protect the Miner's Ridge area of Glacier Peak from mining exploration and development, conservationists urged its inclusion in the national park. For a fascinating discussion of Miner's Ridge and the ramifications associated with its omission from North Cascades National Park, see John McPhee, Encounters with the Archdruid (New York: Farrar, Straus and Giroux, 1971) 3-75. David Brower expressed his disappointment with the exclusion of the Glacier Peak Wilderness Area from the North Cascades National Park in his second autobiography. See Brower, Work in Progress, 54.

${ }^{214}$ David Brower to George Cushman, 7 September 1960, SCOEDR, carton 23, folder 33.

${ }^{215}$ See Brower, Work in Progress, 54-64.
} 
skill with the camera, command of language, and natural storytelling ability are evident throughout the movie. From Brower's introduction to film in the late 1930s to the production of Wilderness Alps of Stehekin, he refined his filmmaking ability through advice from talented friends and practice. Brower's earlier films advocating for the protection of Kings Canyon and Dinosaur National Monument gave him the necessary experience for making a quality film about the North Cascades. Ultimately, his talent and skill as a filmmaker was crucial in helping to protect one of America's most spectacular landscapes. 


\section{Bibliography}

Manuscript Collections:

North Cascades Conservation Council Records (NCCCR). Special Collections. University of Washington Libraries, Seattle.

Sierra Club Office of the Executive Director Records (SCOEDR). Bancroft Library. University of California Libraries, Berkeley.

Other Sources:

Avery, Abigail. "Nurturing the Earth: North Cascades, Alaska, New England, and Issues of War and Peace." Interview conducted by Polly Kaufman, 1988. In The Sierra Club Nationwide IV. Berkeley: Regional Oral History Office, Bancroft Library, University of California, 1996.

Brower, David R. "Wilderness Alps of Stehekin.” The Living Wilderness, Autumn 1958.

— . "Crisis in the North Cascades: The Missing Million." Sierra Club Bulletin, February 1959.

—_. "Environmental Activist, Publicist, and Prophet." Interviews conducted by Susan Schrepfer, 1974-78. Berkeley: Regional Oral History Office, Bancroft Library, University of California, 1980.

. For Earth's Sake: The Life and Times of David Brower. Salt Lake City: Gibbs Smith, 1990.

—. Work in Progress. Salt Lake City: Gibbs Smith, 1991.

Brower, Kenneth. The Wildness Within: Remembering David Brower. Berkeley: Heyday, 2012.

Interview by author, 27 November 2012, Berkeley, CA. Audio recording in author's collection.

Cohen, Michael P. The History of the Sierra Club: 1892-1970. San Francisco: Sierra Club Books, 1988.

Danner, Lauren. "Cultural Values and Communication Content: The Environment and Washington State in the 1960s.” PhD dissertation, University of Oregon, 1999.

Dyer, Polly. "Preserving Parklands and Wilderness." Interview conducted by Susan 
Schrepfer, 1983. In Pacific Northwest Conservationists. Berkeley: Regional Oral History Office, Bancroft Library, University of California, 1986.

Dunaway, Finis. Natural Visions: the Power of Images in American Environmental Reform. Chicago: University of Chicago Press, 2005.

Evans, Brock. Interview by author, 23 October 2012, Washington, DC. Audio recording in author's collection.

Fox, Stephen. The American Conservation Movement: John Muir and His Legacy. Madison: University of Wisconsin Press, 1981.

Glover, James M. A Wilderness Original: The Life of Bob Marshall. Seattle: Mountaineers, 1986.

Goldsworthy, Patrick D. "Protecting the North Cascades, 1954-1983." Interview by Ann Lage, 1983. In Pacific Northwest Conservationists. Berkeley: regional Oral History Office, Bancroft Library, University of California, 1986.

Harvey, Mark W. T. A Symbol of Wilderness: Echo Park and the American Conservation Movement. Albuquerque: University of New Mexico Press, 1994.

Hays, Samuel P. Beauty, Health, and Permanence: Environmental Politics in the United States, 1955-1985. Cambridge: Cambridge University Press, 1987.

Hirt, Paul W. A Conspiracy of Optimism: Management of the National Forests Since World War Two. Lincoln: University of Nebraska Press, 1994.

Louter, David. Contested Terrain: North Cascades National Park Service Complex, an Administrative History. Seattle: National Park Service, 1998.

- Windshield Wilderness: Cars, Roads, and Nature in Washington's National Parks. Seattle: University of Washington Press, 2006.

Manning, Harvey. The Wild Cascades: Forgotten Parkland. The Exhibit-Format Series, editor David Brower. San Francisco: Sierra Club, 1965.

- "You Don't Have to be Old to be an Elder: Elder of the Tribe: Dave Simons (1936-1960).” Backpacker, Spring 1975.

Wilderness Alps: Conservation and Conflict in Washington's North Cascades. Edited by Ken Wilcox. Bellingham: Northwest Wild Books, 2007.

Marsh, Kevin R. Drawing Lines in the Forest: Creating Wilderness Areas in the Pacific Northwest. Seattle: University of Washington Press, 2007. 
McCloskey, J. Michael, ed. Prospectus for a North Cascades National Park. Seattle: North Cascades Conservation Council, 1963.

\section{collection.}

McConnell, Ann. Interview by author, 4 October 2012, Stehekin, WA. Audio recording in author's collection.

McConnell, Grant. "Conservation and Politics in the North Cascades." Interview conducted by Rod Holmgren, 1982. In The Sierra Club Nationwide I. Berkeley: Regional Oral History Office, Bancroft Library, University of California, 1983.

—. Stehekin: A Valley in Time. Seattle: The Mountaineers, 1988.

McPhee, John. Encounters with the Archdruid. New York: Farrar, Straus and Giroux, 1971.

Mitman, Gregg. Reel Nature: America's Romance with Wildlife on Film. Cambridge, MA: Harvard University Press, 1999.

Nash, Roderick Frazier. Wilderness $\&$ the American Mind, $4^{\text {th }}$ edition. New Haven: Yale University Press, 2001.

North Cascades Study Team. The North Cascades: A Report to the Secretary of the Interior and the Secretary of Agriculture. Washington, DC: U.S. Department of the Interior and U.S. Department of Agriculture, 1965.

Oakes, John B. Conservation: Program to Save the Wilds." New York Times (1923Current File), May 05, 1957. http://search.proquest.com/docview/113984140?accountid=13265.

Simons, David. "The Need for Scenic Resource Conservation in the Northern Cascades of Washington.” Brief, San Francisco, 1958.

Sommarstrom, Allan R. "Wild Land Preservation Crisis: The North Cascades Controversy." PhD dissertation, University of Washington, 1970.

Wilderness Alps of Stehekin. 31-minutes, 16mm film, written and narrated by David Brower. 1958. 